Article

\title{
Theoretical Calculations for Highly Selective Direct Heteroarylation Polymerization: New Nitrile-Substituted Dithienyl-Diketopyrrolopyrrole-Based Polymers
}

\author{
Thomas Bura ${ }^{1,+}$, Serge Beaupré ${ }^{1,+}$, Marc-André Légaré ${ }^{2}$, Olzhas A. Ibraikulov ${ }^{3}$ (D), \\ Nicolas Leclerc ${ }^{4}$ and Mario Leclerc ${ }^{1, *(D)}$ \\ 1 Canada Research Chair on Electroactive and Photoactive Polymers, Department of Chemistry, \\ Université Laval, Quebec City, QC G1V 0A6, Canada; thomas.bura.1@ulaval.ca (T.B.); \\ serge.beaupre.1@ulaval.ca (S.B.) \\ 2 Institut für Anorganische Chemie, Julius-Maximilians Universität Würzburg, Am Hubland, \\ 97074 Würzburg, Germany; marcandrelegare@gmail.com \\ 3 Laboratoire ICube, DESSP, Université de Strasbourg, CNRS, 23 rue du Loess, 67037 Strasbourg, France; \\ ibraikulov@unistra.fr \\ 4 Institut de Chimie et Procédés pour l'Énergie, l'Environnement et la Santé, ICPEES, \\ Université de Strasbourg, CNRS, 67087 Strasbourg, France; leclercn@unistra.fr \\ * Correspondence: Mario.Leclerc@chm.ulaval.ca \\ + These authors contributed equally to this work.
}

Academic Editors: Roman Dembinski and Derek J. McPhee

Received: 3 August 2018; Accepted: 11 September 2018; Published: 12 September 2018

check for updates

\begin{abstract}
Direct Heteroarylation Polymerization (DHAP) is becoming a valuable alternative to classical polymerization methods being used to synthesize $\pi$-conjugated polymers for organic electronics applications. In previous work, we showed that theoretical calculations on activation energy $\left(E_{a}\right)$ of the $\mathrm{C}-\mathrm{H}$ bonds were helpful to rationalize and predict the selectivity of the DHAP. For readers' convenience, we have gathered in this work all our previous theoretical calculations on $\mathrm{E}_{\mathrm{a}}$ and performed new ones. Those theoretical calculations cover now most of the widely utilized electron-rich and electron-poor moieties studied in organic electronics like dithienyl-diketopyrrolopyrrole (DT-DPP) derivatives. Theoretical calculations reported herein show strong modulation of the $\mathrm{E}_{\mathrm{a}}$ of $\mathrm{C}-\mathrm{H}$ bond on DT-DPP when a bromine atom or strong electron withdrawing groups (such as fluorine or nitrile) are added to the thienyl moiety. Based on those theoretical calculations, new cyanated dithienyl-diketopyrrolopyrrole (CNDT-DPP) monomers and copolymers were prepared by DHAP and their electro-optical properties were compared with their non-fluorinated and fluorinated analogues.
\end{abstract}

Keywords: DHAP; selectivity; theoretical calculations; conjugated polymers; organic electronics

\section{Introduction}

Organic solar cells (OSCs) and organic field-effect transistors (OFETs) based on $\pi$-conjugated polymers are widely studied to create efficient, lightweight and flexible electronic devices using inexpensive and environmentally friendly printing techniques [1-6]. With power conversion efficiency (PCE) exceeding 10\% [7-11] and OFETs with hole mobility up to $20 \mathrm{~cm}^{2} \mathrm{~V}^{-1} \mathrm{~s}^{-1}$ [12] and electron mobility as high as $7.0 \mathrm{~cm}^{2} \mathrm{~V}^{-1} \mathrm{~s}^{-1}$ [13], conjugated polymers have now reached performances suitable for commercial applications. This is especially true if these materials can be prepared from a low-cost, eco-friendly, reliable and scalable polymerization method such as direct heteroarylation polymerization 
(DHAP). Indeed, DHAP is becoming a valuable alternative to classical polymerization methods used in organic electronics. Despite its recent development, this new polymerization method has already been the subject of several comprehensive reviews and book chapters [14-22]. Significant work is underway to understand and limit some unwanted reactions such as $\beta$-branching and homocoupling when several C-H bonds can be activated during the polymerization. New catalytic systems [23-25], $\beta$-protecting group with no harm on the backbone coplanarity [26] and theoretical calculations on activation energy of $\mathrm{C}-\mathrm{H}$ bonds [27] are among the actual tools to better understand, limit and eliminate such unwanted reactions.

Among all materials studied in organic electronics, 2,5-dihydropyrrolo[3,4-c]pyrrole-1,4-dione (DPP)-based polymers are on the short list of materials that show high performances in both OSCs (PCE up to 9.4\%) [28] and OFETs (hole mobility up to $10.5 \mathrm{~cm}^{2} \mathrm{~V}^{-1} \mathrm{~s}^{-1}$ ) [29]. Since the first report on the synthesis of 3,6-diphenyl-DPP by Farnum et al. in 1974 [30], DPP-based copolymers have been extensively studied and reviewed [31-34]. The flanking aromatic substituents (five- or six-membered-fused or unfused heterocyclic rings) strongly modulate the electro-optical properties. Flanking thiophenes have minimal steric effects on the DPP core and lead to co-planar dithienyl-DPP building blocks (DT-DPP). Recently, we have reported that fluorination of dithienyl-DPP-based monomers (fDT-DPP) is a valuable strategy to obtain well-defined, defect-free DPP-based copolymers by DHAP with enhanced performances in OSCs and OFETs compared to their non-fluorinated analogues [26]. Indeed, a PCE of 7.5\% was obtained for fDT-DPP/carbazole copolymer which was twice that of non-fluorinated counterpart. This PCE value is among the highest values reported so far for OSCs based on conjugated polymers obtained by DHAP [35,36].

Besides fluorination, other electron-withdrawing substituent such as nitrile groups have also been used in conjugated polymers to tailor their electronic properties [37-47]. As reported in the literature, cyanation of the conjugated backbone is an efficient strategy to modulate the electro-optical properties of conjugated polymers and in some cases, it can lead to materials with better performances compared to their fluorinated analogues [48]. The nitrile group is a strong electron-withdrawing group that strongly stabilizes the LUMO energy level (without raising the HOMO level) which contributes to reduce the band gap of the resulting copolymers $[43,46]$. Nitrile groups have also been shown to induce strong dipole moments and promote balanced ambipolar charge transport [49,50]. The main drawback of the cyanation on the conjugated backbone is the lower solubility compared to their non-cyanated analogues which lead to low molecular weight materials with limited processability [42].

In this work, we have summarized all of our theoretical calculations performed on activation energy of the $\mathrm{C}-\mathrm{H}$ bonds of most of the widely used electron-rich and electron-poor moieties studied in organic electronics. In previous work, we found that the $\mathrm{E}_{\mathrm{a}}$ values were helpful to rationalize and predict regio-selectivity of the DHAP when multiple $\mathrm{C}-\mathrm{H}$ bonds can be activated during the polymerization [26,27]. Based on new theoretical calculations, we then synthesized cyanated dithienyl-Diketopyrrolopyrrole (CNDT-DPP) derivatives suitable for DHAP. CNDT-DPP comonomers were then polymerized with either dithienyl-DPP (DT-DPP) or 2,7-dibromocarbazole derivatives and the electro-optical properties of the resulting CNDT-DPP copolymers were compared with their non-cyanated and fluorinated analogues.

\section{Results and Discussion}

\subsection{Theoretical Calculations}

DFT calculations at the B3LYP/TZVP (DZVP for palladium) level have been carried out to evaluate the activation barrier of the $\mathrm{C}-\mathrm{H}$ bond activation of the Concerted-Metalation Deprotonation (CMD) pathway during DHAP. The model palladium catalyst $\left(\mathrm{PMe}_{3}\right) \mathrm{Pd}(\mathrm{Ph})\left(\mathrm{CH}_{3} \mathrm{COO}-\right)$ was used as a platform to calculate the Gibbs free energy of the CMD transition state associated to the activation of the different $\mathrm{C}-\mathrm{H}$ bonds of each substrate. The activation energy ( $\mathrm{E}_{\mathrm{a}}$, Figures 1 and 2$)$ refers to the Gibbs free energy of the CMD transition state referenced to the substrate and model catalyst $\left(\Delta \mathrm{G}^{\ddagger} 298\right)$ 
as reported in previous studies $[26,27,51,52]$. These calculations are relevant to $\alpha$ versus $\beta$ selectivity of DHAP for possible $\beta$-defects but do not say anything about potential $\alpha$ - $\alpha$ homocouplings. From those theoretical calculations, it is also possible to estimate (using Arrhenius's law) a selectivity ratio between $\mathrm{H}_{\alpha}$ and $\mathrm{H}_{\beta}$ at the temperature of polymerization [26]. More importantly, these calculations reveal the importance of the pairing of the comonomers used in DHAP.

Indeed, the data indicate that the presence of bromine atoms (Figures 1 and 2) decreases the energy of activation $\left(E_{a}\right)$ of the adjacent $C-H$ bonds, allowing undesirable $\beta$-defects for some brominated aromatic units. For instance, if we utilized the DHAP with Br-BDT-Me or Br-BDT-OMe and DPP (Figure 1); the difference in the activation energy $\left(\Delta \mathrm{E}_{\mathrm{a}}\right)$ between $\mathrm{H}_{\alpha}$ and $\mathrm{H}_{\beta}$ for the DPP moiety is found to be $4.8 \mathrm{kcal} \cdot \mathrm{mol}^{-1}$ (24.2 vs. $29.0 \mathrm{kcal} \cdot \mathrm{mol}^{-1}$, respectively), which lead to a ratio of about 250:1 favoring $\mathrm{H}_{\alpha}$ (using Arrhenius's law). On the other hand, the $\mathrm{E}_{\mathrm{a}}$ of the $\mathrm{H}_{\beta}$ of the Br-BDT-Me is $28.2 \mathrm{kcal} \cdot \mathrm{mol}^{-1}$ whereas the $\mathrm{E}_{\mathrm{a}}$ for $\mathrm{H}_{\beta}$ on the Br-BDT-OMe is only $26.7 \mathrm{kcal} \cdot \mathrm{mol}^{-1}$. Using these values, the $\Delta \mathrm{E}_{\mathrm{a}}$ between $\mathrm{H}_{\alpha}$ of DPP $\left(24.2 \mathrm{kcal} \cdot \mathrm{mol}^{-1}\right)$ and the $\mathrm{H}_{\beta}$ of the Br-BDT-OMe $\left(26.7 \mathrm{kcal} \cdot \mathrm{mol}^{-1}\right)$ and Br-BDT-Me $\left(28.2 \mathrm{kcal} \cdot \mathrm{mol}^{-1}\right)$ are respectively of 2.5 and $4.0 \mathrm{kcal} \cdot \mathrm{mol}^{-1}$, giving respective selectivity of about $25: 1$ and $160: 1$ at $125^{\circ} \mathrm{C}$. Although the $1.5 \mathrm{kcal} \cdot \mathrm{mol}^{-1}$ difference might look small, it indicates that the activation of the $\mathrm{H}_{\beta}$ of the Br-BDT-OMe may occur about one order of magnitude faster than the one of the $\mathrm{H}_{\beta}$ of the Br-BDT-Me resulting in more $\beta$-defects, while the polymer using Br-BDT-Me will better behave in term of selectivity.

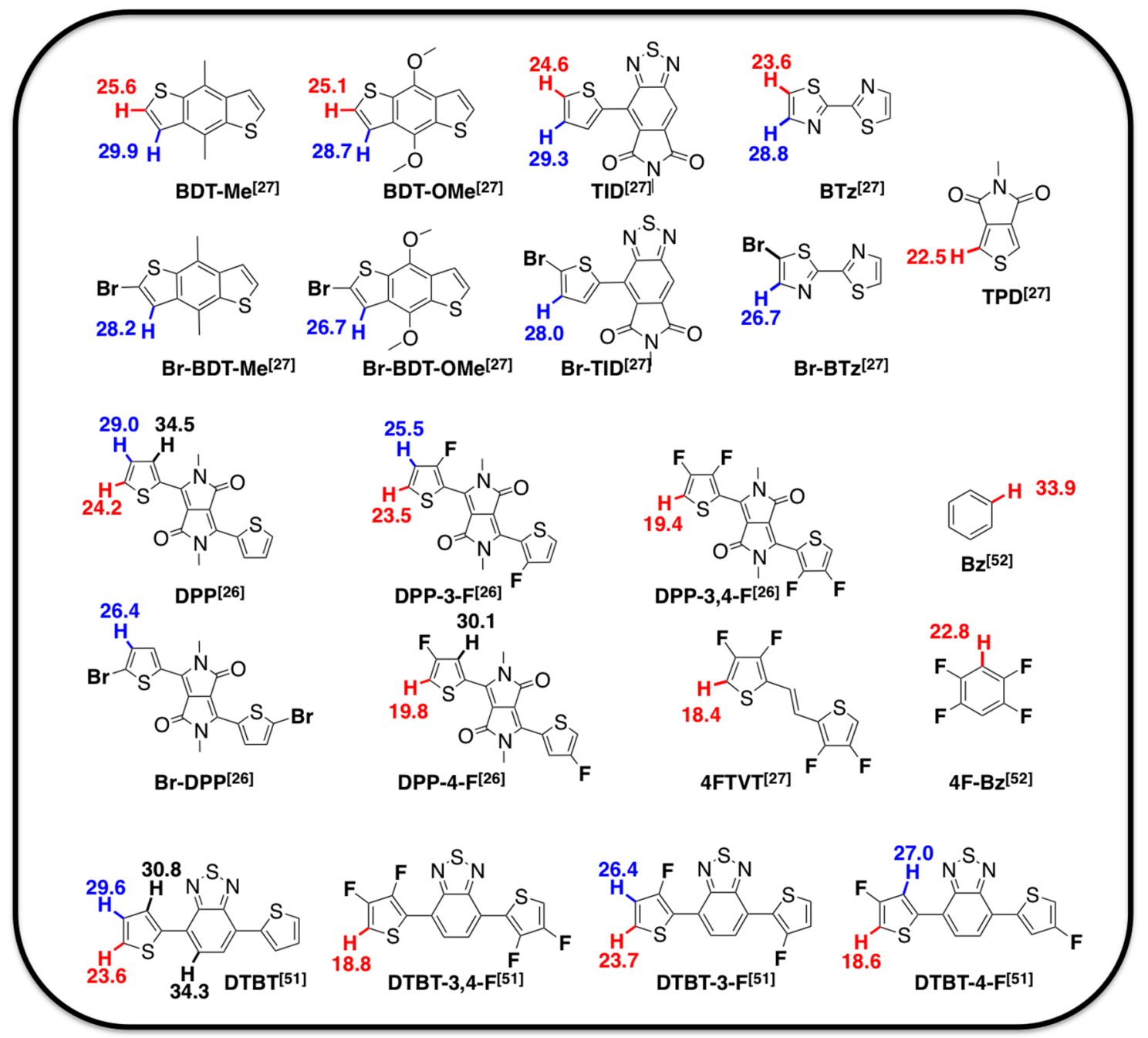

Figure 1. Gibbs free energy of the CMD transition state associated to the transition state for the $\mathrm{C}-\mathrm{H}$ bond cleavage (previous work: [26,27,51,52]). 


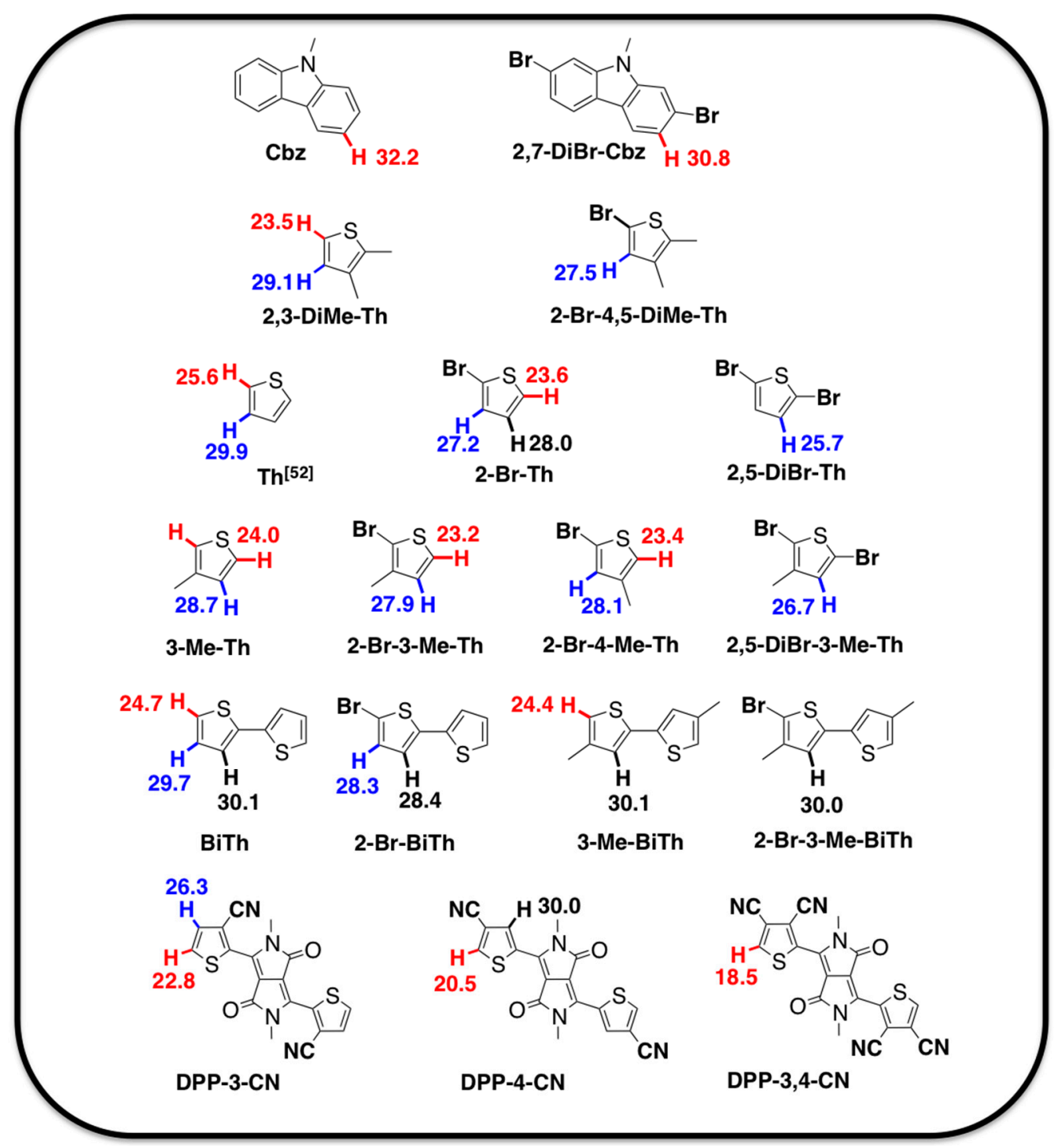

Figure 2. Gibbs free energy of the CMD transition state associated to the transition state for the $\mathrm{C}-\mathrm{H}$ bond cleavage (this work [52]).

These calculations indicate that some brominated monomers are not intrinsically inadequate but their utilization is strongly dependent upon the nature and reactivity of the respective comonomer. This has been proven by the work of Li et al. [53]. Indeed, well-defined copolymer was obtained from the copolymerization of Br-DPP with bithiazole (BTz) while poor performances were obtained for the same copolymer synthesized using Br-BTz and DPP. For the first case, the $\Delta \mathrm{E}_{\mathrm{a}}$ between the $\mathrm{H}_{\alpha}$ $\left(23.6 \mathrm{kcal} \cdot \mathrm{mol}^{-1}\right)$ and $\mathrm{H}_{\beta}\left(28.8 \mathrm{kcal} \cdot \mathrm{mol}^{-1}\right)$ of BTz is $5.2 \mathrm{kcal} \cdot \mathrm{mol}^{-1}$ which means that the activation of the $\mathrm{H}_{\alpha}$ position is highly selective (ratio 1152:1). Meanwhile, a selectivity of about 35:1 is observed when considering the $\Delta \mathrm{E}_{\mathrm{a}}$ value of $2.8 \mathrm{kcal} \cdot \mathrm{mol}^{-1}$ between $\mathrm{H}_{\beta}$ of the Br-DPP $\left(26.4 \mathrm{kcal} \cdot \mathrm{mol}^{-1}\right)$ and $\mathrm{H}_{\alpha}$ of the BTz $\left(23.6 \mathrm{kcal} \cdot \mathrm{mol}^{-1}\right)$. On the other hand, for the Br-BTz/DPP system, the $\Delta \mathrm{E}_{\mathrm{a}}$ between $\mathrm{H}_{\beta}$ of the Br-BTz $\left(26.7 \mathrm{kcal} \cdot \mathrm{mol}^{-1}\right)$ and the $\mathrm{H}_{\alpha}$ of the DPP $\left(24.2 \mathrm{kcal} \cdot \mathrm{mol}^{-1}\right)$ is $2.5 \mathrm{kcal} \cdot \mathrm{mol}^{-1}$ (ratio $23: 1$ ) and should lead to less-defined structure.

\subsection{Justification for Cyano-Dithienyl-DPP (CNDT-DPP)}

Lately, we have shown that the fluorination of flanking thiophene (at the 3- or 4-position) influences the electro-optical properties and the coplanarity of the DPP-based copolymers and to obtain a coplanar fluorinated DPP, the fluorine atom has to be installed at the 4-position of 
thiophene ring [26,51]. A fluorine atom at the 4-position on flanking thiophene strongly decreases the activation energy of the adjacent $\mathrm{C}-\mathrm{H}$ bond (from $24.2 \mathrm{kcal} \cdot \mathrm{mol}^{-1}$ to $19.8 \mathrm{kcal} \cdot \mathrm{mol}^{-1}$ ) for DPP moiety (Figure 1). We then performed a similar study by replacing the fluorine atom by a nitrile group, a strong electron-withdrawing moiety. As shown in Figure 2, the nitrile groups have also a strong influence on the adjacent $\mathrm{C}-\mathrm{H}$ bonds. Indeed, we found a $\Delta \mathrm{E}_{\mathrm{a}}$ of $3.7 \mathrm{kcal} \cdot \mathrm{mol}^{-1}$ for $\mathrm{H}_{\alpha}$ of DPP-4-CN $\left(20.5 \mathrm{kcal} \cdot \mathrm{mol}^{-1}\right)$ vs DPP $\left(24.2 \mathrm{kcal} \cdot \mathrm{mol}^{-1}\right)$ and $4.5 \mathrm{kcal} \cdot \mathrm{mol}^{-1}$ for $\mathrm{H} \gamma$ of DPP-4-CN $\left(30.0 \mathrm{kcal} \cdot \mathrm{mol}^{-1}\right) \mathrm{vs}$. DPP $\left(34.5 \mathrm{kcal} \cdot \mathrm{mol}^{-1}\right)$. Although, the activation energy of $\mathrm{H} \gamma$ is decreased by $4.5 \mathrm{kcal} \cdot \mathrm{mol}^{-1}$ compared to DPP, a selectivity of about 500,000/1 in favor of $\mathrm{H}_{\alpha}$ over $\mathrm{H} \gamma$ was calculated using Arrhenius's law. This means that polymerization reaction should mainly occur at the $\alpha$-position and lead to well-defined materials. The same trend was observed for DPP-3-CN vs. DPP-3-F and DPP-3,4-CN vs. DPP-3,4-F. Keeping in mind the need for coplanar copolymers, only DPP-4-CN was synthesized (Scheme 1) and copolymerized by DHAP (Scheme 2).
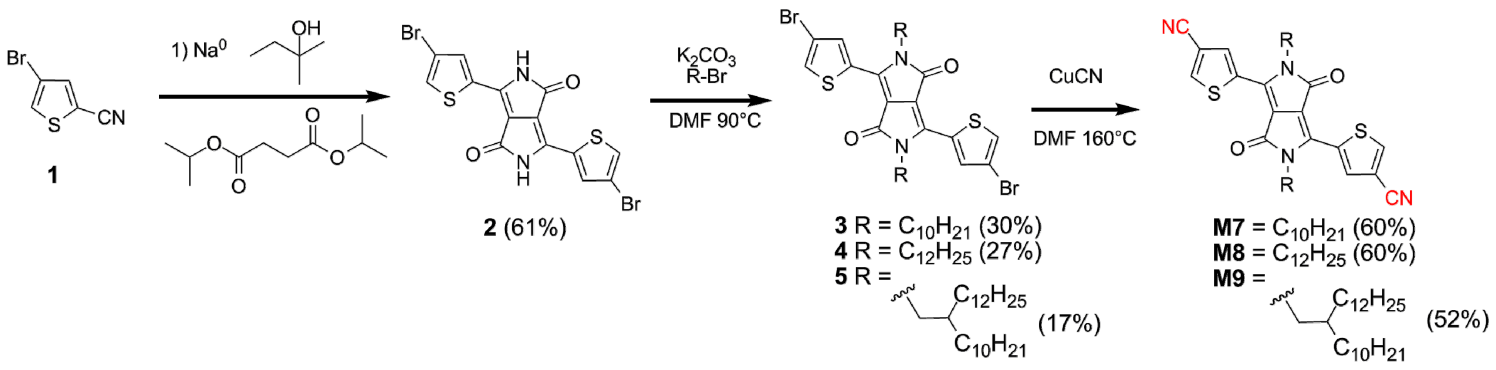

Scheme 1. Synthetic Pathway for the Synthesis of CN-DPP Comonomers M7, M8 and M9.

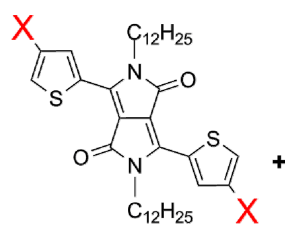

$$
\begin{aligned}
& X=H, M 3 \\
& X=F,{ }^{|54|} \\
& X=\text { CN, M8 }
\end{aligned}
$$<smiles>[X]c1csc(C2=C3C(=O)N([R])C(c4cc([X])cs4)=C3C(=O)N2[R])c1</smiles>

$X=H, R=C_{10} H_{21}, M 4 \mid[60 \mid$ $X=F, R=C_{10} H_{21}, M 6$ $\mathrm{X}=\mathrm{CN}, \mathrm{R}=\mathrm{C}_{10} \mathrm{H}_{21}, \mathrm{M} 7$

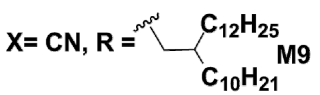

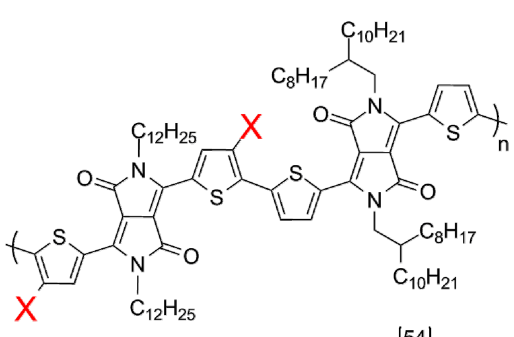

\section{Pd source Ligand

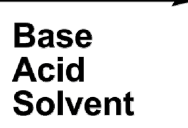

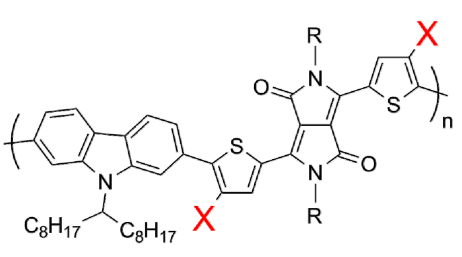

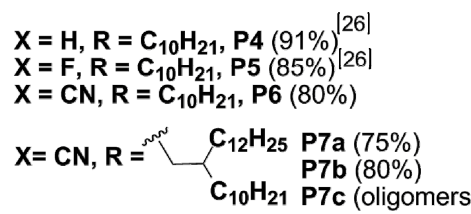

Scheme 2. Monomers and Polymers Investigated in this Work. [26,54-57].

\subsection{Synthesis of Monomers}

A pseudo Stobbe condensation between diisopropyl succinic ester and commercially available 4-bromothiophene-2-carbonitrile (1) in the presence of sodium alkoxide led to 3,6-(4-bromo-thiophen-2-yl)pyrrolo[3,4-c]-pyrrole-1,4-dione (2) in moderate yield (61\%, Scheme 1). In the next step, a typical alkylation reaction of the DPP core was performed using either 1-bromodecane, 1-bromododecane or 1-bromo-2-decyltetradecane and allowed us to obtain 
corresponding alkylated DPP 3-5 in low yields (17-30\%). Finally, the target monomers M7-M9 (see Supplementary Materials) were obtained in good yield by cyanation of the respective brominated DPP through a Rosenmund-von Braun cyano-dehalogenation reaction with $\mathrm{CuCN}$ in hot anhydrous DMF as described in the literature [49]. For comparison purposes, M7-M9 were obtained in three steps with an overall yield of 10\% while M5 and M6 (fDT-DPP analogues) [26] were obtained in seven steps with an overall yield of $8 \%$.

\subsection{Synthesis and Characterization of Polymers}

P3, P6 and P7 were prepared by direct (hetero)arylation polymerization (DHAP) following methodologies previously reported in the literature (Scheme 2) [26]. Cyanated dithienyl-DPP (CNDT-DPP) pseudo-homopolymer P3 was synthesized for future OFETs applications while CNDT-DPP/carbazole copolymers P6, P7 were designed to be used as an electron-donor in OSCs. According to theoretical calculations, the reaction between Br-DPP M1 and DPP-4-CN M8 (Figures 1 and 2) should proceed smoothly without $\beta$-branching on the DPP-4-CN or on the Br-DPP moieties. Indeed, the $\beta$-position is protected by the nitrile group on the DPP-4-CN and the $\mathrm{H}_{\alpha}$ has an $\mathrm{E}_{\mathrm{a}}$ of $20.5 \mathrm{kcal} \cdot \mathrm{mol}^{-1}$ while the $\mathrm{E}_{\mathrm{a}}$ of $\mathrm{H}_{\beta}$ on the $\mathrm{Br}-\mathrm{DPP}$ is $26.4 \mathrm{kcal} \cdot \mathrm{mol}^{-1}$. The $\Delta \mathrm{E}_{\mathrm{a}}$ between $\mathrm{H}_{\beta}$ of $\operatorname{Br}-\mathrm{DPP}\left(26.4 \mathrm{kcal} \cdot \mathrm{mol}^{-1}\right)$ and the $\mathrm{H}_{\alpha}$ of DPP-4-CN $\left(20.5 \mathrm{kcal} \cdot \mathrm{mol}^{-1}\right)$ is $5.9 \mathrm{kcal} \cdot \mathrm{mol}^{-1}$ which lead to an estimated selectivity of 1800:1 in favor of the $\mathrm{H}_{\alpha}$ of the DPP-4-CN. The same reasoning should also apply for $\mathbf{P 6}$ involving the reaction between M2 (Scheme 2) and M7 (Figure 2). The $\beta$-position on DPP-4-CN is protected by the nitrile group and the $\Delta \mathrm{E}_{\mathrm{a}}$ between $\mathrm{H}_{\alpha}$ of DPP-4-CN $\left(20.5 \mathrm{kcal} \mathrm{mol}^{-1}\right)$ and the $\mathrm{H}_{\alpha}$ of $\mathrm{Br}-\mathrm{Cbz}\left(30.8 \mathrm{kcal} \cdot \mathrm{mol}^{-1}\right)$ is $10.3 \mathrm{kcal} \cdot \mathrm{mol}^{-1}$ which lead to an estimated selectivity of 687,000:1 in favor of the $\mathrm{H}_{\alpha}$ of DPP-4-CN. It is worth nothing that P3 and P6 were synthesized using the same catalytic conditions as those used for their fluorinated analogues [26]. Unlike fDT-DPP based copolymers P2 [26], the polymerization reaction of P3 was stopped rapidly (10 min) due to gelation of the reaction mixture.

As shown in Table 1, the polymerization time for P3 (10 min) and P6 (40 min) were shorter compared to the polymerization times of DT-DPP analogues (1200 min for P1 and $960 \mathrm{~min}$ for P4). As for fDT-DPP comonomers, the shorter polymerization times compared to those observed for the non-fluorinated are due to strong electron-withdrawing effect of the cyano group on the $\alpha \mathrm{C}-\mathrm{H}$ bond. Moreover, the polymerization times for $\mathbf{P 6}$ vs $\mathbf{P 5}$ were similar which might mean that the reactivity of M7 and M6 are similar, which is in good agreement with the $\mathrm{E}_{\mathrm{a}}$ of DPP-4-CN $\left(20.5 \mathrm{kcal} \cdot \mathrm{mol}^{-1}\right) \mathrm{vs}$. $\mathrm{E}_{\mathrm{a}}$ of DPP-4-F (19.8 $\left.\mathrm{kcal} \cdot \mathrm{mol}^{-1}\right)$. Unlike P2, we were unable to determine the molecular weights of P3 due to strong aggregation and limited solubility, even in TCB at $135^{\circ} \mathrm{C}$. On the other hand, the molecular weight of P6 (soluble fraction) was lower compared to P4 and P5. The short polymerization time (40 $\mathrm{min}$ ), due to rapid gelation of the reaction mixture, led to a material with low molecular weight. In the hope of promoting the solubility of CNDT-DPP/Carbazole copolymers, long and branched alkyl side chains were installed on the CNDT-DPP moiety (see M9 in Scheme 1). P7a was obtained by DHAP from M2 and M9 using the same catalytic system used for the synthesis of $\mathbf{P 6}$ but in more dilute conditions in superheated tetrahydrofuran $\left(C=0.085 \mathrm{~mol} \cdot \mathrm{L}^{-1}\right.$ for $\mathbf{P 7 a} \mathrm{vs} . \mathrm{C}=0.1 \mathrm{~mol} \cdot \mathrm{L}^{-1}$ for P6). Despite a longer polymerization time before gelation of the reaction mixture happened for P7a (240 min), a lower molecular weight material was obtained. P7b was then synthesized using the same polymerization conditions used for $\mathbf{P 6}\left(\mathrm{C}=0.1 \mathrm{~mol} \cdot \mathrm{L}^{-1}\right.$ in THF). As for P6, gelation of the polymerization mixture was observed after only $40 \mathrm{~min}$. Despite higher $\overline{M_{n}}\left(35 \mathrm{~kg} \mathrm{~mol}{ }^{-1}\right)$ the degree of polymerization of $\mathbf{P 7 b}$ and $\mathbf{P 6}$ are the same (DP $=24)$. Finally, P7c was synthesized using chlorobenzene instead of THF $\left(\mathrm{C}=0.1 \mathrm{~mol} \cdot \mathrm{L}^{-1}\right)$ but the polymerization did not work and only oligomers were recovered. P6 was then used for comparison purposes with P4 and P5 since these polymers have the same side chains installed on the DPP moiety. 
Table 1. Characterization of P1-P7a-c.

\begin{tabular}{cccccc}
\hline & $\overline{\boldsymbol{M}_{\boldsymbol{n}}}$ & $\mathbf{D}$ & Yield & Reaction Time & $\mathbf{T}_{\mathbf{d}}$ \\
\cline { 2 - 6 } & $\mathbf{k g ~ m o l}^{\mathbf{- 1}}$ & & $\mathbf{\%}$ & $\mathbf{m i n}$ & ${ }^{\circ} \mathbf{C}$ \\
\hline P1 [54] & 16 & 2.4 & 93 & 1200 & n.a \\
P2 [26] & 22 & 3.0 & 73 & 1200 & 430 \\
P3 & n.a. & n.a. & 65 & 10 & 420 \\
P4 [26] & 44 & 3.0 & 91 & 960 & 420 \\
P5 [26] & 125 & 3.0 & 85 & 30 & 420 \\
P6 & 25 & 3.5 & 80 & 40 & 405 \\
P7a & 20 & 1.7 & 75 & 240 & 405 \\
P7b & 35 & 2.4 & 80 & 40 & 410 \\
P7c & \multicolumn{5}{c}{ oligomers }
\end{tabular}

Thermal properties were evaluated by thermogravimetric analysis (TGA) and differential scanning calorimetry (DSC). All polymers exhibit good thermal stability with $5 \%$ weight loss at temperature higher than $400{ }^{\circ} \mathrm{C}$ (see Table 1). Differential scanning calorimetry measurements did not reveal any thermal transition. NMR spectroscopy was useless to identify any defect within the conjugated backbone for $\mathbf{P 3}$ and $\mathbf{P 6}$ due to broad and featureless signals.

The UV-Vis-NIR absorption spectroscopy (solution and film) was performed to gauge the effect of substituents at 4-position on flanking thiophene DPP core on the optical properties and the results are summarized in Table 2. The absorption spectra of P1-P6 are shown in Figures 3 and 4. In dilute chloroform solution, a bathochromic shift of the maximum of absorption (19 $\mathrm{nm}$ ) was observed for P6 (674 nm) compared to $\mathbf{P 4}(655 \mathrm{~nm})$. In the same condition, a hypsochromic shift of $28 \mathrm{~nm}$ was observed for the maximum of absorption of $\mathbf{P 6}(674 \mathrm{~nm})$ compared to the maximum of absorption of $\mathbf{P 5}(702 \mathrm{~nm})$. Beside the fact that $\overline{M_{n}}$ of P5 $\left(125 \mathrm{~kg} \mathrm{~mol}^{-1}\right)$ is much higher than $\mathbf{P 6}\left(25 \mathrm{~kg} \mathrm{~mol}^{-1}\right)$, the optical band gaps were found to be almost identical (1.68 eV for $\mathbf{P 6}$ and $1.65 \mathrm{eV}$ for P5). The hypsochromic shift observed for $\mathbf{P 6}$ is due to a conformational twisting of the conjugated backbone due to the larger size of the nitrile group compared to fluorine which was confirmed by conformational analyses performed on the repeating unit of $\mathbf{P 5}$ and $\mathbf{P 6}$ (Figure 5). The calculations suggest that P6 is more twisted than P5 $\left(30.6^{\circ}\right.$ vs. $\left.24.0^{\circ}\right)$, which should reduce the effective length of conjugation of the polymer.

Table 2. Electro-optical properties of P1-P6.

\begin{tabular}{|c|c|c|c|c|c|c|c|}
\hline & \multirow{2}{*}{ HOMO $^{a}$} & \multirow{2}{*}{ LUMO $^{a}$} & \multirow{2}{*}{$E_{g}^{c v}$} & \multirow{2}{*}{ LUMO $^{b}$} & \multicolumn{2}{|c|}{$\lambda_{\max }$} & \multirow{2}{*}{$E_{g}^{o p t}$} \\
\hline & & & & & Solution & Film & \\
\hline & $\mathrm{eV}$ & $\mathrm{eV}$ & eV & $\mathrm{eV}$ & $\mathrm{nm}$ & $\mathrm{nm}$ & $\mathrm{eV}$ \\
\hline P1 [54] & -5.13 & -3.82 & 1.31 & -3.96 & $820 / 920$ & $846 / 927$ & 1.17 \\
\hline P2 [26] & -5.35 & -3.69 & 1.66 & -4.20 & $887 / 962$ & $859 / 967$ & 1.15 \\
\hline P3 & -5.44 & -3.96 & 1.48 & -4.28 & 907 & 881 & 1.16 \\
\hline P4 [26] & -5.11 & -3.46 & 1.65 & -3.43 & $622 / 655$ & $630 / 689$ & 1.68 \\
\hline P5 [26] & -5.33 & -3.61 & 1.72 & -3.68 & $639 / 702$ & $639 / 702$ & 1.65 \\
\hline P6 & -5.54 & -3.79 & 1.75 & -3.86 & $621 / 674$ & $620 / 676$ & 1.68 \\
\hline $\mathrm{P} 7 \mathrm{a}$ & -5.54 & -3.79 & 1.75 & -3.86 & $620 / 673$ & $621 / 674$ & 1.73 \\
\hline P7b & -5.54 & -3.79 & 1.75 & -3.86 & $621 / 674$ & $621 / 676$ & 1.72 \\
\hline
\end{tabular}

${ }^{\mathrm{a}}$ from CV measurements. ${ }^{\mathrm{b}} \mathrm{E}_{\mathrm{LUMO}}=\mathrm{E}_{\mathrm{HOMO}}+E_{g}^{o p t}$. 


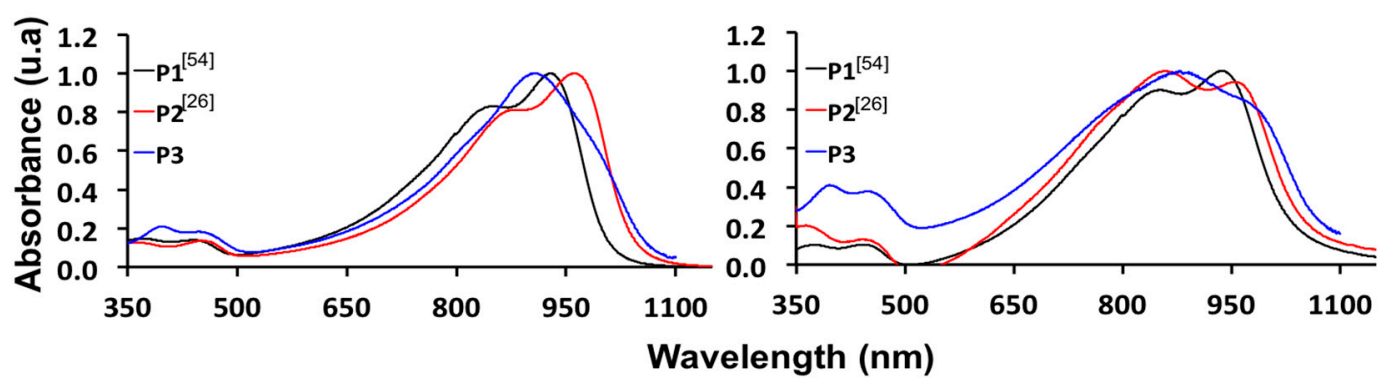

Figure 3. UV-Visible absorption spectra of $\mathbf{P 1 - P 3}$ in solution in $\mathrm{CHCl}_{3}$ (left) and in the solid state (right) [26,54].

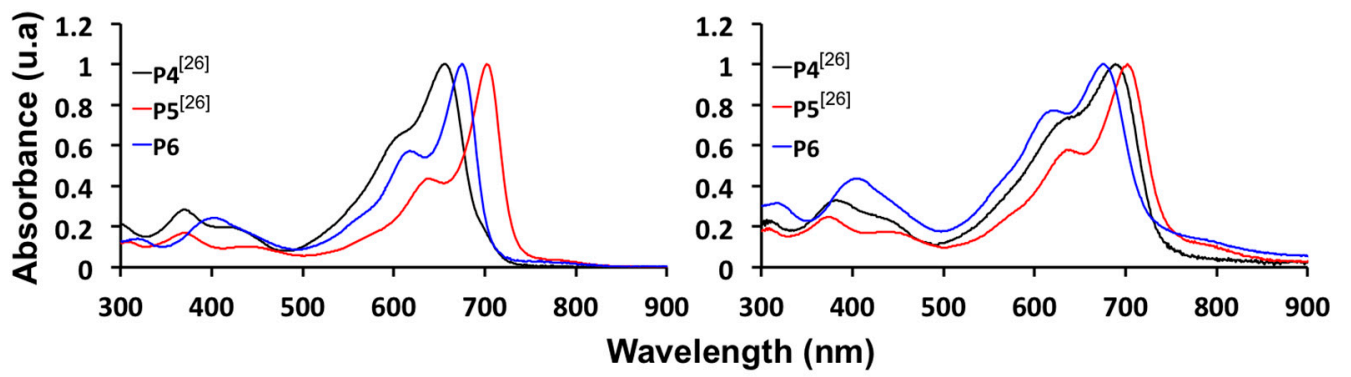

Figure 4. UV-Visible absorption spectra of $\mathbf{P 4 - \mathbf { P } 6}$ in solution in $\mathrm{CHCl}_{3}$ (left) and in the solid state (right) [26].

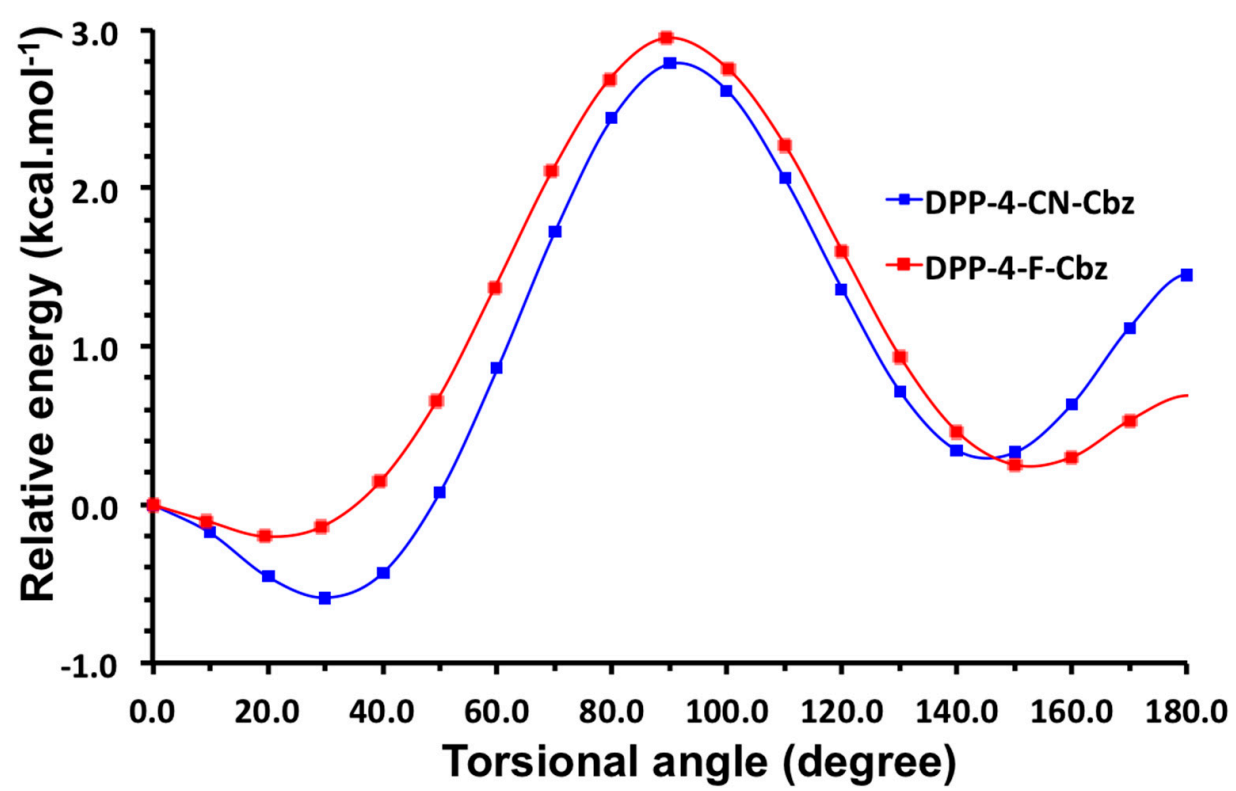

Figure 5. Ground-state energy surfaces of CBz-DPP-4-F and CBz-DPP-4-CN dimers.

Electrochemical measurements such as cyclic voltammetry are a widely used method in organic electronics to estimate the HOMO and LUMO energy levels analyses. In order to be able to compare the values reported in literature, it is of the utmost importance that the measurements are performed under the same conditions (electrolyte, working electrode, reference electrode (non-aqueous is highly desirable), scanning speed, determination of the onset oxidation and reduction, and calibration against Ferrocene). Comparisons between datasets can be therefore misleading. Lately, we found that some $\mathrm{HOMO} / \mathrm{LUMO}$ values reported might have been over-estimated. This issue has been fixed and the HOMO/LUMO values reported in Table 2 reflects those changes. As example, we have previously reported for P1 a HOMO energy level of $-5.45 \mathrm{eV}$ and a LUMO energy level of $-4.14 \mathrm{eV}$ [54]. After corrections the HOMO and LUMO energy levels are now $-5.13 \mathrm{eV}$ and $-3.82 \mathrm{eV}$, which is in 
good agreement with DPP-based polymers reported in literature [33]. The same corrections have been done for P2 and P5 previously reported in literature [26]. For P1-P3, a stabilization of the HOMO energy level was observed upon fluorination and cyanation of the DPP moiety (Figure 6).
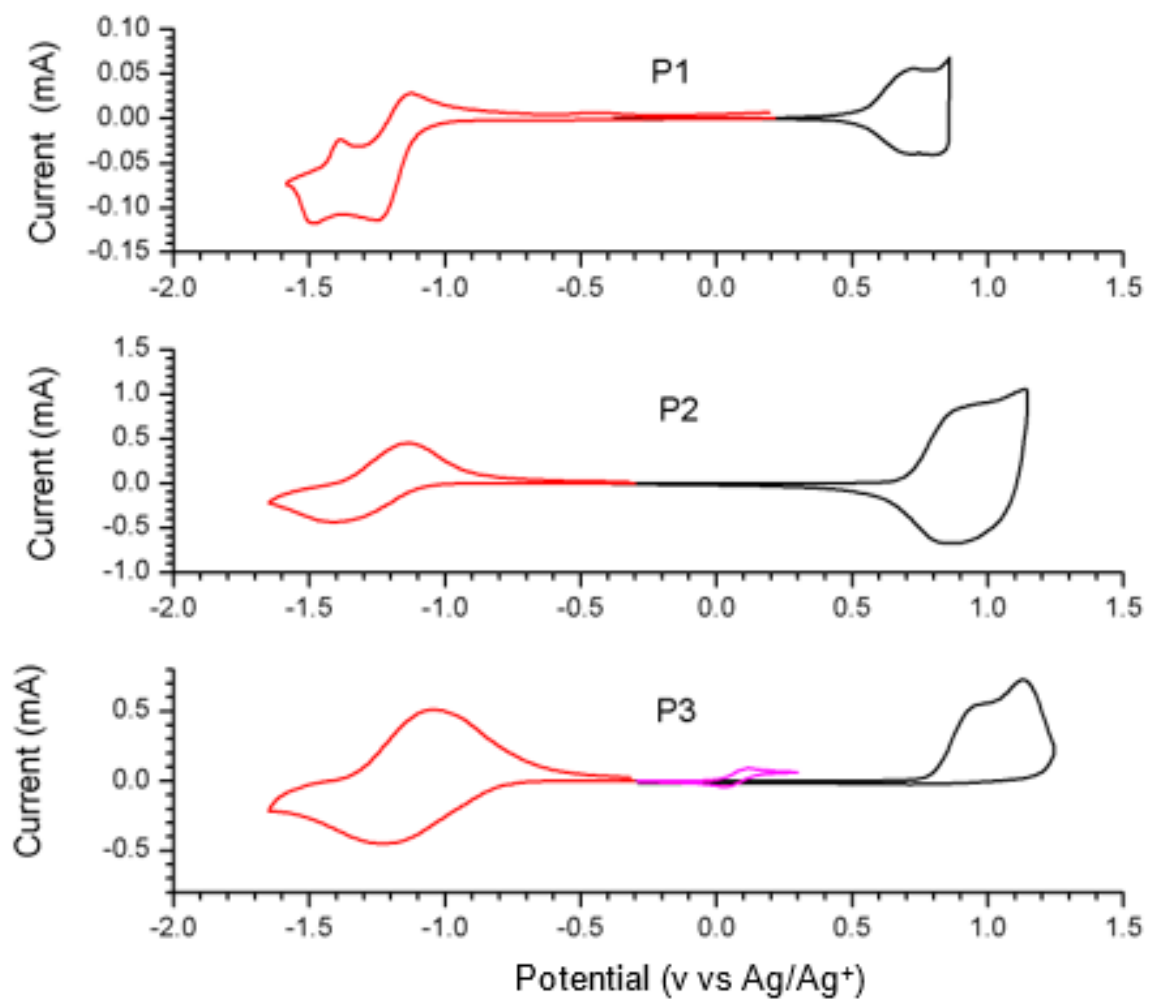

Figure 6. Cyclic voltammetry of P1 [54], P2 [26] and P3 (In magenta, Fc/Fc+).

Indeed, the HOMO level of $\mathbf{P 2}(-5.35 \mathrm{eV})$ was stabilized by $0.22 \mathrm{eV}$ while the HOMO level of P3 $(-5.44 \mathrm{eV})$ was stabilized by $0.31 \mathrm{eV}$ compared to HOMO level of P1 $(-5.13 \mathrm{eV})$. The same trend was observed for P4-P6 (Figure 7). The stabilization of the HOMO level due to cyanation of DPP moiety was even larger for $\mathbf{P 6}(0.43 \mathrm{eV})$. These data are in good agreement with the trend observed for the cyanation of conjugated polymers. It is worth nothing that deeper HOMO energy levels might lead to a higher open circuit voltage $\left(\mathrm{V}_{\mathrm{oc}}\right)$ in OSCs. On the other hand, the LUMO energy levels were also determined from cyclic voltammetry even though reduction measurements are more sensitive to water and oxygen. While the estimated LUMO energy levels obtained by cyclic voltammetry for P4-P6 (Figure 8) led to $E_{g}^{c v}$ similar to $E_{g}^{o p t}$, it was not the case for the P1-P3 (Figure 6). Indeed, even if reversible reduction processes were observed for each polymer, the band gap (calculated from the reduction and the oxidation onsets) led to $E_{g}^{c v}$ values that did not match the optical band gap calculated from solid state UV-Vis absorption spectra (Table 2). We found a $\Delta \mathrm{E}_{\mathrm{g}}$ between $E_{g}^{c v}$ and $E_{g}^{o p t}$ of $0.14 \mathrm{eV}$, $0.51 \mathrm{eV}$ and $0.32 \mathrm{eV}$ for P1, P2 and P3 respectively. Even if stabilization of the LUMO energy levels was observed upon cyanation of the DT-DPP moiety $(-3.82 \mathrm{eV}$ to $-3.96 \mathrm{eV}$, Figure 6), it appears that the reduction processes observed for P1 to P3 might not correspond to the extraction of electron from the conjugated skeleton but may come from the reduction of other functional group found on the DPP moiety. As reported in literature, the discrepancy between the electrochemical and optical band gaps may also be ascribed to the strong exciton binding energy in conjugated polymers. This binding energy can be as high as 0.4-1.0 eV [58-60]. We then calculated the LUMO energy levels using the optical band gap and the HOMO energy levels (Table 2). Going from P1 to P3, we noticed a steady stabilization of the LUMO energy levels $-3.96 \mathrm{eV},-4.20 \mathrm{eV}$ and $-4.28 \mathrm{eV}$. These deep LUMO energy levels make $\mathbf{P} 2$ and $\mathbf{P} 3$ good candidates for $n$-type materials for OFETs or good electron-acceptor in all 
polymer solar cells (PSCs). P3 and P6 are currently tested in OFETs and PSCs and those results will be reported in a forthcoming paper.

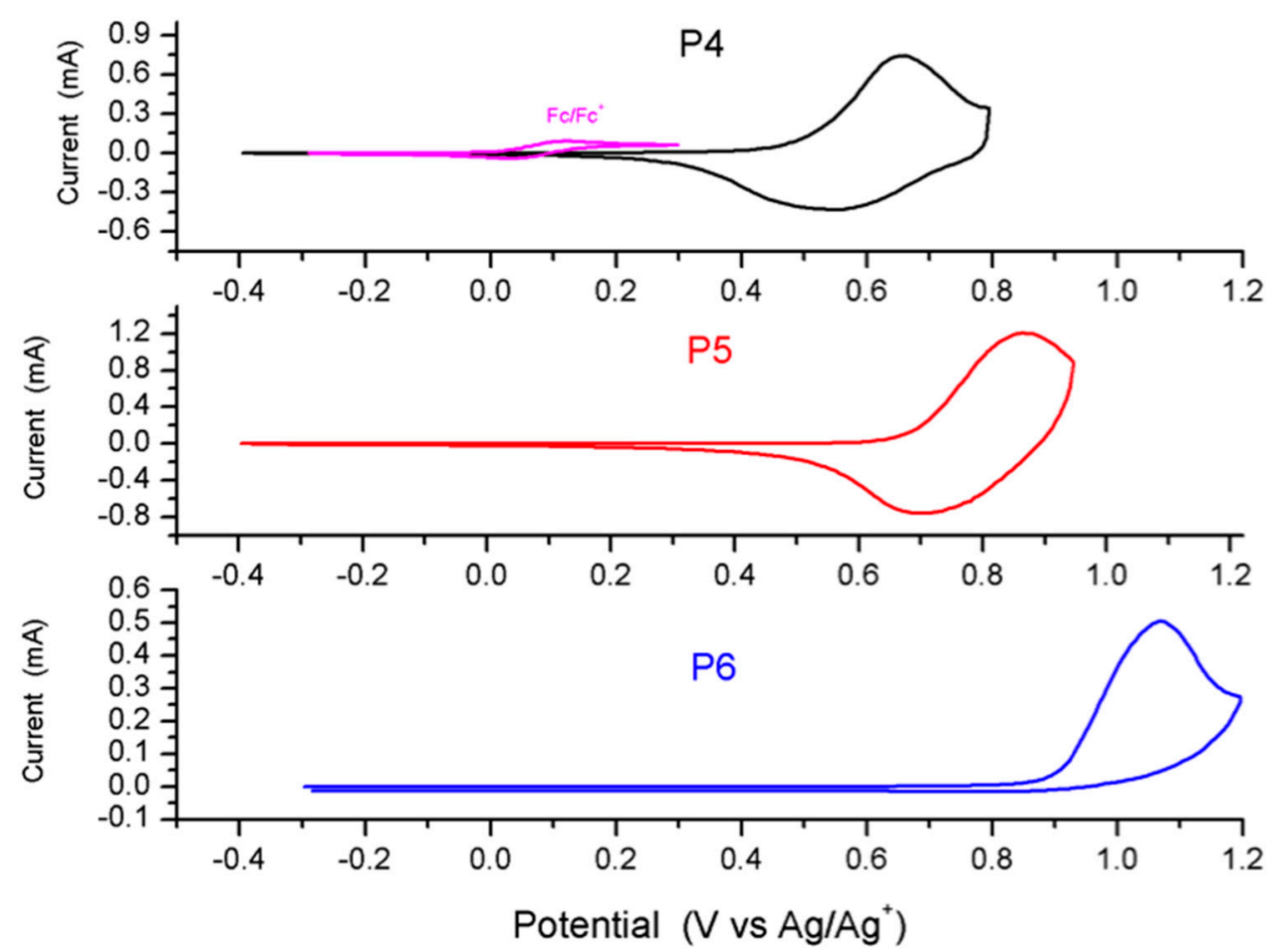

Figure 7. Cyclic voltammetry of P4 [26], P5 [26] and P6.

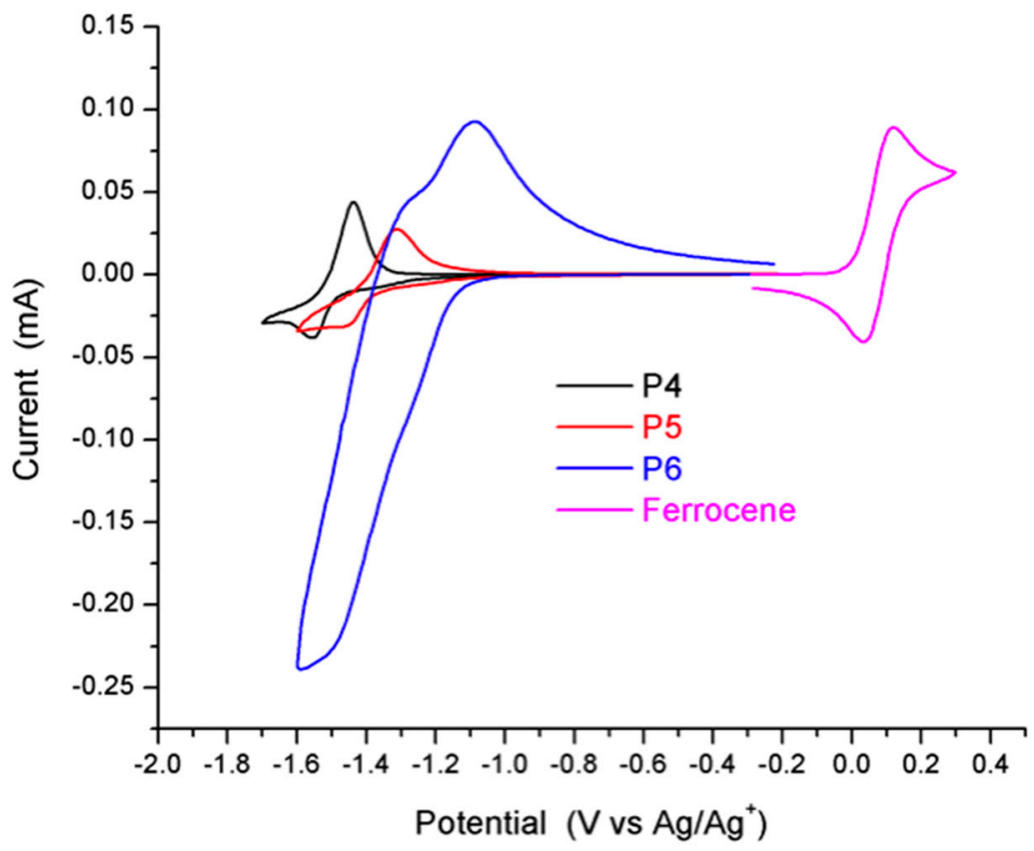

Figure 8. Cyclic voltammetry of P4 [26], P5 [26] and P6 (Reduction only).

\section{Materials and Methods}

${ }^{1} \mathrm{H}$ and ${ }^{13} \mathrm{C}$-NMR spectra were recorded on a Varian AS400 or Agilent DD2 $500 \mathrm{MHz}$ apparatus (Santa Clara, CA, USA) in deuterated solvents. Chemical shifts were reported as $\delta$ values (ppm) relative to the residual protic solvent (see Supplementary Materials). Infrared Spectra were obtained using a Specac spectrometer using golden gate single reflection attenuated total reflection system 
(Pleasantville, NY, USA) fitted with a diamond crystal. The infrared spectra were recorded in solid state with a Nicolet Magna 550 Fourier transform spectrometer (Madison, WI, USA) equipped with a narrow band mercury-cadmiun-telluride (MCT) detector and a germanium-coated KBr beam splitter. A total of 64 interferograms were acquired, co-added and Fourier transformed to give a spectral resolution of $4 \mathrm{~cm}^{-1}$ in the spectral range of $4000-800 \mathrm{~cm}^{-1}$. High resolution mass spectra were recorded with a time-of-flight spectrometer in flow infusion analysis on an Agilent Technologies 1200 series system (Santa Clara, CA, USA). Ions were generated by a Kr UV lamp in an APPI source with toluene/anisole mixture as dopant when required. Spectra ranging from 100 to $3200 \mathrm{~m} / \mathrm{z}$ were recorded with typical resolution of 5000 to 15,000 and typical precision of \pm 1 ppm or less. The mass analyzer was calibrated with standard solutions provided by the manufacturer and covering the spectral range described above. The number-average $\left(\overline{M_{n}}\right)$ and weight-average $\left(\overline{M_{W}}\right)$ molecular weights were determined by size exclusion chromatography (SEC) using a Varian Polymer Laboratories PL-GPC 120 (Church Stretton, Shropshire, United Kingdom). The column set consists of 2 PL gel Mixed C $(300 \times 7.5 \mathrm{~mm})$ columns and a PL gel Mixed C guard column. The flow rate was fixed at $1 \mathrm{~mL} / \mathrm{min}$ using 1,2,4-trichlorobenzene (TCB) (with $0.0125 \%$ BHT $w / v$ ) as eluent. The temperature of the system was set to $110{ }^{\circ} \mathrm{C}$. All the samples were prepared at concentrations of nominally $1.0 \mathrm{mg} / \mathrm{mL}$ in TCB. Dissolution was performed using a Varian Polymer Laboratories PL-AS RT autosampler. The sample vials were held at $110{ }^{\circ} \mathrm{C}$ with shaking for $1 \mathrm{~h}$ for complete dissolution. The solutions were filtered through a $2 \mathrm{~mm}$ porous stainless steel filter used with the $0.40 \mu \mathrm{m}$ glass filter into a $2 \mathrm{~mL}$ chromatography vial. The calibration method used to generate the reported data was the classical polystyrene method using polystyrene narrow standards Easi-Vials PS-M from Varian Polymer Laboratories which were dissolved in TCB. UV-Vis absorption spectra were taken using a Thermo Scientific Genesys 10 S spectrophotometer (Madison, WI, USA) using $1 \mathrm{~cm}$ path-length quartz cells. For solid state measurements, polymer solution was spun-cast on glass plates. Optical bandgaps were calculated from the onset of the absorption band. Thermogravimetric analysis (TGA) measurements were carried out with a Mettler Toledo TGA SDTA 851e apparatus (Colombus, OH, USA) at a heating rate of $10{ }^{\circ} \mathrm{C} / \mathrm{min}$ under a nitrogen atmosphere. The temperature of degradation (Td) corresponds to a $5 \%$ weight loss. Differential scanning calorimetry (DSC) analysis was performed on a Mettler Toledo DSC823e apparatus (Colombus, OH, USA) calibrated with ultrapure indium at a scanning rate of $10^{\circ} \mathrm{C} / \mathrm{min}$ under a nitrogen flow. Cyclic voltammograms were recorded on a Solartron 1287 potentiostat (Oak Ridge, TN, USA) using platinum wires as working electrode and counter electrode at a scan rate of $50 \mathrm{mV} / \mathrm{s}$. The reference electrode was $\mathrm{Ag} / \mathrm{Ag}^{+}(0.01 \mathrm{M} \mathrm{AgNO} 3$ in acetonitrile), and the electrolyte was a solution of $0.1 \mathrm{M}$ tetrabutylammonium tetrafluoroborate $\left(\mathrm{Bu}_{4} \mathrm{NBF}_{4}\right)$ in $\mathrm{dry}$ acetonitrile. In these conditions, the half-wave oxidation potential of ferrocene was $0.091 \mathrm{~V}$ versus $\mathrm{Ag} / \mathrm{Ag}+\left(E_{\text {Ferrocene vs. } \mathrm{Ag} / \mathrm{Ag}^{+}}^{1 / 2}\right)$. The HOMO and LUMO energy levels were determined from the oxidation and reduction onsets $\left(\mathrm{E}^{\prime}\right)$ (where the current differs from the baseline) using the following equations:

$$
\begin{aligned}
& \mathrm{E}_{\mathrm{HOMO}}=-\left[\left(E_{\text {ox vs. } A g / A g^{+}}^{\prime}\right)+4.8-\left(E_{\text {Ferrocene vs. } A g / A g^{+}}^{1 / 2}\right)\right] \\
& \mathrm{E}_{\mathrm{LUMO}}=-\left[\left(E_{\text {red vs. } A g / A g^{+}}^{\prime}\right)+4.8-\left(E_{\text {Ferrocene vs. } A g / A g^{+}}^{1 / 2}\right)\right]
\end{aligned}
$$

\subsection{Materials}

4-Bromothiophene-2-carbonitrile (1) was purchased from Combiblocks (San Diego, CA, USA). P1 [54], P2 [26], P4 [26], P5 [26], 3,6-bis(5-bromothiophen-2-yl)-2,5-bis(2-octyl-dodecyl) pyrrolo[3,4-c]pyrrole-1,4)-dione (M1) [55], 2,7-dibromo-9-(heptadecan-9-yl)-9H-carbazole (M2) [56], 3,6-bis(thiophen-2-yl)-2,5-bis(dodecyl)pyrrolo[3,4-c]pyrrole-1,4-dione (M3) [54], 3,6-bis-(thiophen2-yl)-2,5-bis(decyl)-pyrrolo[3,4-c]pyrrole-1,4-dione(M4) [57], 3,6-(4-fluorothiophen-2-yl)-2,5-Bis (dodecyl)pyrrolo[3,4-c]pyrrole-1,4-dione (M5) [26], 3,6-(4-fluorothiophen-2-yl)-2,5-Bis(decyl)pyrrolo [3,4-c]pyrrole-1,4-dione (M6) [26] and 4-tris(2-cycloheptyloxyphenyl)phosphine (Bura-Phos) [27] were synthesized according to literature. 


\subsection{Synthesis of Monomers and Polymers}

\subsubsection{Synthesis of 3,6-(4-Bromothiophen-2-yl)pyrrolo[3,4-c]-pyrrole-1,4-dione (2)}

In a two-neck flask equipped with a condenser and an addition funnel, sodium $(3.67 \mathrm{~g}, 0.159 \mathrm{~mol}$, 1.2 eq.) was added in 2-methyl-2-butanol $\left(250 \mathrm{~mL}\right.$, and the mixture was heated at $105{ }^{\circ} \mathrm{C}$ until complete consumption of the sodium. Then, 4-bromo-2-thiophenecarbonitrile (1, $25 \mathrm{~g}, 0.133 \mathrm{~mol}, 1$ eq.) was rapidly added into the mixture, and diisopropyl succinate (12.1 g, $59.8 \mathrm{mmol}, 0.45 \mathrm{eq}$.) was slowly added through the addition funnel. The reaction mixture quickly turned purple. The reaction mixture was stirred overnight at $105^{\circ} \mathrm{C}$. The reaction was cooled at $65^{\circ} \mathrm{C}$ and quenched by an addition of a mixture of methanol $(150 \mathrm{~mL})$ and acetic acid $(70 \mathrm{~mL})$ followed by heating at $90{ }^{\circ} \mathrm{C}$ for $30 \mathrm{~min}$. Then, the reaction mixture was allowed to cool to room temperature, filtered on a Buchner, and washed with methanol to give a purple solid $(\mathrm{Y}=61 \%)$.

\subsubsection{Synthesis of 3,6-(4-Bromothiophen-2-yl)-2,5-bis(decyl)-pyrrolo[3,4-c]pyrrole-1,4-dione (3)}

In a two-neck flask equipped with a condenser and an addition funnel, compound 2 (1.150 g, $2.51 \mathrm{mmol}, 1$ eq.) and anhydrous potassium carbonate $(1.1 \mathrm{~g}, 7.53 \mathrm{mmol}, 3$ eq.) were stirred in anhydrous DMF $(8 \mathrm{~mL})$. The mixture was heated at $100{ }^{\circ} \mathrm{C}$ for $30 \mathrm{~min}$, and then 1-bromodecane ( $1.7 \mathrm{~g}, 7.53 \mathrm{mmol}, 3$ eq.) was slowly added. The reaction mixture was stirred overnight at $100{ }^{\circ} \mathrm{C}$. After cooling to room temperature, the reaction was quenched with a saturated solution of $\mathrm{NH}_{4} \mathrm{Cl}$ and extracted three times with diethyl ether. The combined organic phases were washed with water and brine, dried over $\mathrm{MgSO}_{4}$, and concentrated under vacuum. Purification was achieved by column chromatography (silica gel; eluent: chloroform/hexanes 85/15) affording the desired compound as a purple solid $(\mathrm{Y}=30 \%) .{ }^{1} \mathrm{H}-\mathrm{NMR}\left(500 \mathrm{MHz}, \mathrm{CDCl}_{3}\right) \delta(\mathrm{ppm}): 8.81(\mathrm{~s}, 2 \mathrm{H}), 7.52(\mathrm{~s}, 2 \mathrm{H}), 4.02-3.99(\mathrm{~m}$, $4 \mathrm{H}), 1.73-1.70(\mathrm{~m}, 4 \mathrm{H}), 1.42-1.26(\mathrm{~m}, 28 \mathrm{H}), 0.90-0.87(\mathrm{~m}, 6 \mathrm{H}) .{ }^{13} \mathrm{C}-\mathrm{NMR}\left(126 \mathrm{MHz}, \mathrm{CDCl}_{3}\right) \delta(\mathrm{ppm})$ : $169.9,138.8,136.7,130.5,127.7,112.3,108.2,42.3,31.9,29.9,29.6,29.5,29.3,29.2,26.8,22.6,14.1$. m.p. $=$ $126^{\circ} \mathrm{C}$. FTIR $\vee\left(\mathrm{cm}^{-1}\right)=3094,2951,2916,2850,1666,1576,1407,883$. HRMS (APPI+): $m / z$ calcd for $\mathrm{C}_{34} \mathrm{H}_{47} \mathrm{Br}_{2} \mathrm{~N}_{2} \mathrm{O}_{2} \mathrm{~S}_{2}$ : 737.1446; found: $737.1475[\mathrm{M}+\mathrm{H}]^{+}$

\subsubsection{Synthesis of 3,6-(4-Bromo-thiophen-2-yl)-2,5-bis(dodecyl)-pyrrolo[3,4-c]pyrrole-1,4-dione (4)}

Compound 4 was synthesized and purified according to the procedure described for compound 3 using 1-bromododecane instead of 1-bromodecane affording the desired compound as a purple solid $(\mathrm{Y}=27 \%) .{ }^{1} \mathrm{H}-\mathrm{NMR}\left(500 \mathrm{MHz}, \mathrm{CDCl}_{3}\right) \delta(\mathrm{ppm}): 8.81(\mathrm{~s}, 2 \mathrm{H}), 7.52(\mathrm{~s}, 2 \mathrm{H}), 4.02-3.99(\mathrm{~m}, 4 \mathrm{H}), 1.73-1.70$ (m, 4H), 1.42-1.26 (m, 36H), 0.90-0.87 (m, 6H). ${ }^{13} \mathrm{C}-\mathrm{NMR}\left(126 \mathrm{MHz}, \mathrm{CDCl}_{3}\right) \delta$ (ppm): 169.9, 138.8, 136.7, $130.5,127.7,112.3,108.2,42.3,31.9,29.9,29.6,29.56,29.52,29.3,29.2,26.8,22.6,14.1$. m.p. $=132{ }^{\circ} \mathrm{C}$. FTIR $v\left(\mathrm{~cm}^{-1}\right)=3102,2917,2850,1670,1557,1412,876$. HRMS (APPI+): $m / z$ calcd for $\mathrm{C}_{38} \mathrm{H}_{55} \mathrm{Br}_{2} \mathrm{~N}_{2} \mathrm{O}_{2} \mathrm{~S}_{2}$ : 793.2072; found: $793.2083[\mathrm{M}+\mathrm{H}]^{+}$

3.2.4. Synthesis of 3,6-(4-Bromo-thiophen-2-yl)-2,5-di(2'-decyltetradecyl)-pyrrolo[3,4-c]pyrrole1,4-dione (5)

Compound 5 was synthesized and purified according to the procedure described for compound 3 using 1-bromo-2-decyltetradecane instead of 1-bromodecane affording the desired compound as a purple solid $(\mathrm{Y}=17 \%)$. ${ }^{1} \mathrm{H}-\mathrm{NMR}\left(400 \mathrm{MHz}, \mathrm{CDCl}_{3}\right) \delta(\mathrm{ppm}): 8.69(\mathrm{~d}, J=1.4 \mathrm{~Hz}, 2 \mathrm{H}), 7.50(\mathrm{~d}, J=1.4 \mathrm{~Hz}$, 2H), $3.95(\mathrm{~d}, J=7.7 \mathrm{~Hz}, 4 \mathrm{H}), 1.85(\mathrm{~m}, 2 \mathrm{H}), 1.27-1.21(\mathrm{~m}, 80 \mathrm{H}), 0.89-0.85(\mathrm{~m}, 12 \mathrm{H}) .{ }^{13} \mathrm{C}-\mathrm{NMR}(101 \mathrm{MHz}$, $\left.\mathrm{CDCl}_{3}\right) \delta$ (ppm): 161.3, 139.2, 136.4, 130.6, 127.5, 112.1, 108.1, 46.2, 30.0, 29.7, 29.6, 29.5, 29.4, 29.3, 29.2, 22.7, 14.1. HRMS (APPI+): $m / z$ calcd for $\mathrm{C}_{62} \mathrm{H}_{103} \mathrm{Br}_{2} \mathrm{~N}_{2} \mathrm{O}_{2} \mathrm{~S}_{2}: 1129.5828$; found: $1129.5838[\mathrm{M}+\mathrm{H}]^{+}$.

\subsubsection{Synthesis of 3,6-(4-Cyano-thiophen-2-yl)-2,5-bis(decyl)-pyrrolo[3,4-c]pyrrole-1,4-dione (M7)}

In a microwave vial containing compound 3 (230 $\mathrm{mg}, 0.311 \mathrm{mmol} 1 \mathrm{eq}$.$) and copper(I)cyanide$ (223 mg, $2.49 \mathrm{mmol}, 8$ eq.) was added dry DMF ( $\left.3 \mathrm{~mL}, \mathrm{C}=0.75 \mathrm{~mol} \cdot \mathrm{L}^{-1}\right)$. The mixture was heated under argon for $24 \mathrm{~h}$ at $160{ }^{\circ} \mathrm{C}$. The reaction mixture was allowed to cool down to room temperature 
and water was added and the crude was extracted three times with diethyl ether. The aqueous phase was extracted three times with diethyl ether. The solvent was removed under reduced pressure and the residue was purified by column chromatography (chloroform/ethyl acetate, 95/5) affording the desired compound as a purple solid $(\mathrm{Y}=60 \%){ }^{1} \mathrm{H}-\mathrm{NMR}\left(500 \mathrm{MHz}, \mathrm{CDCl}_{3}\right) \delta(\mathrm{ppm}): 8.99(\mathrm{~s}, 2 \mathrm{H}), 8.17$ $(\mathrm{s}, 2 \mathrm{H}), 4.03-4.01(\mathrm{~m}, 4 \mathrm{H}), 1.72-1.69(\mathrm{~m}, 4 \mathrm{H}), 1.42-1.26(\mathrm{~m}, 28 \mathrm{H}), 0.89-0.86(\mathrm{~m}, 6 \mathrm{H}) .{ }^{13} \mathrm{C}-\mathrm{NMR}(126 \mathrm{MHz}$, $\left.\mathrm{CDCl}_{3}\right) \delta$ (ppm): 160.7, 138.7, 138.3, 135.2, 131.1, 113.9, 112.5, 108.8, 42.3, 31.8, 30.1, 29.5, 29.3, 29,2, 26.8, 22.6, 14.1. m.p. $=216^{\circ} \mathrm{C}$. FTIR $v\left(\mathrm{~cm}^{-1}\right)=3081,2914,2846,2233,1667,1559,883$. HRMS (APPI+): $m / z$ calcd for $\mathrm{C}_{36} \mathrm{H}_{47} \mathrm{~N}_{4} \mathrm{O}_{2} \mathrm{~S}_{2}$ : 631.3140; found: $631.3177[\mathrm{M}+\mathrm{H}]^{+}$.

\subsubsection{Synthesis of 3,6-(4-Cyano-thiophen-2-yl)-2,5-bis(dodecyl)-pyrrolo[3,4-c]pyrrole-1,4-dione (M8)}

M8 was synthesized from compound 4 and purified according to the procedure described for M7. $(\mathrm{Y}=60 \%) .{ }^{1} \mathrm{H}-\mathrm{NMR}\left(500 \mathrm{MHz}, \mathrm{CDCl}_{3}\right) \delta(\mathrm{ppm}): 8.99(\mathrm{~s}, 2 \mathrm{H}), 8.16(\mathrm{~s}, 2 \mathrm{H}), 4.03-4.00(\mathrm{~m}, 4 \mathrm{H}), 1.70-1.68$ $(\mathrm{m}, 4 \mathrm{H}), 1.40-1.25(\mathrm{~m}, 36 \mathrm{H}), 0.88-0.86(\mathrm{~m}, 6 \mathrm{H}) .{ }^{13} \mathrm{C}-\mathrm{NMR}\left(126 \mathrm{MHz}, \mathrm{CDCl}_{3}\right) \delta(\mathrm{ppm}): 160.8,138.8$, 138.4, 135.3, 131.3, 114.1, 112.7, 109.0, 42.4, 32.0, 30.1, 29.6, 29.4, 29,3, 26.9, 22.8, 14.2. m.p. $=230{ }^{\circ} \mathrm{C}$. FTIR $v\left(\mathrm{~cm}^{-1}\right)=3088,2919,2850,2236,1674,1559,884$. HRMS (APPI+): $m / z$ calcd for $\mathrm{C}_{40} \mathrm{H}_{55} \mathrm{~N}_{4} \mathrm{O}_{2} \mathrm{~S}_{2}$ : 687.3766; found: $687.3775[\mathrm{M}+\mathrm{H}]^{+}$.

3.2.7. Synthesis of 3,6-(4-Cyano-thiophen-2-yl)-2,5-bis(2-decyltetradecyl)-pyrrolo[3,4-c]pyrrole1,4-dione (M9)

M9 was synthesized from compound 4 and purified according to the procedure described for M7 and M8. $(\mathrm{Y}=52 \%)$. ${ }^{1} \mathrm{H}-\mathrm{NMR}\left(400 \mathrm{MHz}, \mathrm{CDCl}_{3}\right) \delta(\mathrm{ppm}): 8.91(\mathrm{~d}, J=1.2 \mathrm{~Hz}, 2 \mathrm{H}), 8.15(\mathrm{~d}, J=1.2 \mathrm{~Hz}$, 2H), $3.95(\mathrm{~d}, \mathrm{~J}=7.7 \mathrm{~Hz}, 4 \mathrm{H}), 1.78(\mathrm{br}, 2 \mathrm{H}), 1.39-1.09(\mathrm{~m}, 80 \mathrm{H}), 0.96-0.78(\mathrm{~m}, 12 \mathrm{H}) .{ }^{13} \mathrm{C}-\mathrm{NMR}(101 \mathrm{MHz}$, $\left.\mathrm{CDCl}_{3}\right) \delta$ (ppm): 161.1, 139.0, 138.1, 135.1, 131.2, 113.9, 112.4, 109.0, 46.3, 31.9, 29.9, 29.7, 29.6, 29.5, 26.2, 22.6, 14.1. HRMS (APPI+): $m / z$ calcd for $\mathrm{C}_{63} \mathrm{H}_{103} \mathrm{~N}_{4} \mathrm{O}_{2} \mathrm{~S}_{2}: 1023.7522$; found: $1023.7546[\mathrm{M}+\mathrm{H}]^{+}$.

\subsubsection{Synthesis of $\mathbf{P 3}$}

M1 (0.076 mmol, 1 eq.), M8 (0.076 mmol, 1 eq.), trans-bis(acetato)bis[o-(di-o-tolylphosphino)benzyl]dipalladium (II) (2\% mol), tris(2-methoxyphenyl)phosphine ( $8 \% \mathrm{~mol}), \mathrm{Cs}_{2} \mathrm{CO}_{3}$ (3 eq.) and pivalic acid (1 eq.) were put in a microwave vial with a magnetic stirring bar. The vial was sealed with a cap and then purged with nitrogen to remove the oxygen (3X). Degassed and anhydrous toluene was added $\left(\mathrm{C}=0.2 \mathrm{~mol} \cdot \mathrm{L}^{-1}, 0.4 \mathrm{~mL}\right)$ and the microwave vial was heated at $120^{\circ} \mathrm{C}$ using a slow temperature ramp. After heating for $5 \mathrm{~min}$, gelation of the reaction mixture occurred and the reaction was stopped. Chloroform was added to solubilize the mixture $(2 \mathrm{~mL})$ and then the mixture was poured in methanol/acidified water $(10 \% \mathrm{HCl} ; 9: 1$ ratio), and the solid was recovered by filtration using a $0.45 \mu \mathrm{m}$ nylon filter. The polymer was washed using a Soxhlet apparatus with acetone, hexanes, then chloroform. The chloroform fraction was reduced to 5-10 $\mathrm{mL}$ and then poured in methanol. The polymer was recovered by filtration over a $0.45 \mu \mathrm{m}$ nylon filter and dried under vacuum $(\mathrm{Y}=65 \%)$.

\subsubsection{Synthesis of $\mathbf{P} \mathbf{6}$}

M2 (0.12 mmol, 1 eq.), M7 (0.12 mmol, 1 eq.), $\operatorname{Pd}(\mathrm{OAc})_{2} \quad(4 \% \mathrm{~mol})$, tris(2-cycloheptyloxyphenyl)phosphine (BuraPhos) (16\% mol), $\mathrm{Cs}_{2} \mathrm{CO}_{3}$ (3 eq.) and pivalic acid (1 eq.) were put in a microwave vial with a magnetic stirring bar. The vial was sealed with a cap and then purged with nitrogen to remove the oxygen (3X). Degassed and anhydrous THF was added $\left(C=0.1 \mathrm{~mol} \cdot \mathrm{L}^{-1}\right.$, $1.2 \mathrm{~mL}$ ) and the reaction was heated with an oil bath pre-heated at $100{ }^{\circ} \mathrm{C}$ (reaction under pressure) until gelation of the reaction mixture. After $40 \mathrm{~min}$, gelation of the reaction mixture occurred and the reaction was stopped. The reaction was cooled to $65^{\circ} \mathrm{C}$ and then $2 \mathrm{~mL}$ of ODCB was added and the mixture was heated at $100{ }^{\circ} \mathrm{C}$ for $5 \mathrm{~min}$. The mixture was poured in methanol/acidified water $(10 \% \mathrm{HCl} ; 9: 1$ ratio), and the solid was recovered by filtration using a $0.45 \mu \mathrm{m}$ nylon filter. The polymer was washed using a Soxhlet apparatus with acetone, hexane, and then chlorobenzene. 
The chlorobenzene fraction was reduced to $5-10 \mathrm{~mL}$ and then poured in methanol. The polymer was recovered by filtration over a $0.45 \mu \mathrm{m}$ nylon filter and dried under vacuum $(\mathrm{Y}=80 \%)$.

\subsubsection{Synthesis of P7a}

M9 (0.143 mmol, 1 eq.), M7 (0.143 mmol, 1 eq.), $\mathrm{Pd}(\mathrm{OAc})_{2}(4 \% \mathrm{~mol})$, tris(2-cycloheptyloxyphenyl)phosphine (BuraPhos) (16\% mol), $\mathrm{Cs}_{2} \mathrm{CO}_{3}$ (3 eq.) and pivalic acid (1 eq.) were put in a microwave vial with a magnetic stirring bar. The vial was sealed with a cap and then purged with nitrogen to remove the oxygen (3X). Degassed and anhydrous THF was added $\left(\mathrm{C}=0.085 \mathrm{~mol} \cdot \mathrm{L}^{-1}\right.$, $1.7 \mathrm{~mL}$ ) and the reaction was heated with an oil bath pre-heated at $100{ }^{\circ} \mathrm{C}$ (reaction under pressure). After $4 \mathrm{~h}$ the reaction was stopped. The reaction was cooled to $65^{\circ} \mathrm{C}$ and then $2 \mathrm{~mL}$ of ODCB was added and the mixture was heated at $100{ }^{\circ} \mathrm{C}$ for $5 \mathrm{~min}$. The mixture was poured in methanol/acidified water $(10 \% \mathrm{HCl} ; 9: 1$ ratio), and the solid was recovered by filtration using a $0.45 \mu \mathrm{m}$ nylon filter. The polymer was washed using a Soxhlet apparatus with acetone and hexanes. The hexanes fraction was reduced to 5-10 $\mathrm{mL}$ and then poured in methanol. The polymer was recovered by filtration over a $0.45 \mu \mathrm{m}$ nylon filter and dried under vacuum $(Y=75 \%)$.

\subsubsection{Synthesis of $\mathbf{P 7 b}$}

M9 $(0.13 \mathrm{mmol}, 1$ eq. $)$, M7 $(0.13 \mathrm{mmol}, 1$ eq. $), \operatorname{Pd}(\mathrm{OAc})_{2}(4 \% \mathrm{~mol})$, tris(2-cycloheptyloxyphenyl)phosphine (BuraPhos) (16\% mol), $\mathrm{Cs}_{2} \mathrm{CO}_{3}$ (3 eq.) and pivalic acid (1 eq.) were put in a microwave vial with a magnetic stirring bar. The vial was sealed with a cap and then purged with nitrogen to remove the oxygen (3X). Degassed and anhydrous THF was added $\left(\mathrm{C}=0.15 \mathrm{~mol} \cdot \mathrm{L}^{-1}\right.$, $0.9 \mathrm{~mL}$ ) and the reaction was heated with an oil bath pre-heated at $100{ }^{\circ} \mathrm{C}$ (reaction under pressure) until gelation of the reaction mixture. After $40 \mathrm{~min}$, gelation of the reaction mixture occurred and the reaction was stopped. The reaction was cooled to $65^{\circ} \mathrm{C}$ and then $2 \mathrm{~mL}$ of ODCB was added and the mixture was heated at $100{ }^{\circ} \mathrm{C}$ for $5 \mathrm{~min}$. The mixture was poured in methanol/acidified water $(10 \%$ $\mathrm{HCl} ; 9: 1$ ratio), and the solid was recovered by filtration using a $0.45 \mu \mathrm{m}$ nylon filter. The polymer was washed using a Soxhlet apparatus with acetone, hexanes and chloroform. The chloroform fraction was reduced to $5-10 \mathrm{~mL}$ and then poured in methanol. The polymer was recovered by filtration over a $0.45 \mu \mathrm{m}$ nylon filter and dried under vacuum $(\mathrm{Y}=80 \%)$.

\subsubsection{Synthesis of P7c}

M9 (0.143 mmol, 1 eq.), M7 (0.143 mmol, 1 eq.), $\mathrm{Pd}(\mathrm{OAc})_{2}(4 \% \mathrm{~mol})$, tris(2-cycloheptyloxyphenyl)phosphine (BuraPhos) $(16 \% \mathrm{~mol}), \mathrm{Cs}_{2} \mathrm{CO}_{3}$ (3 eq.) and pivalic acid (1 eq.) were put in a microwave vial with a magnetic stirring bar. The vial was sealed with a cap and then purged with nitrogen to remove the oxygen (3X). Degassed and anhydrous Chlorobenzene was added $\left(\mathrm{C}=0.1 \mathrm{~mol} \cdot \mathrm{L}^{-1}, 1.4 \mathrm{~mL}\right.$ ) and the reaction was heated with an oil bath pre-heated at $130{ }^{\circ} \mathrm{C}$ (reaction under pressure). After $24 \mathrm{~h}$ the reaction was stopped. The reaction was cooled to $65^{\circ} \mathrm{C}$ was poured in methanol/acidified water $(10 \% \mathrm{HCl} ; 9: 1$ ratio), and the solid was recovered by filtration using a $0.45 \mu \mathrm{m}$ nylon filter. The polymer was washed using a Soxhlet apparatus using acetone and only oligomers were recovered.

\section{Conclusions}

We have performed theoretical calculations on new electron-rich and electron-poor compounds for applications in organic electronics. These results led to the design and synthesis of new cyanated dithienyl-diketopyrrolopyrrole units (CNDT-DPP) that were suitable for the direct heteroarylation polymerization. Two classes of cyanated dithienyl-DPP-based copolymers (pseudo-homopolymer (P3) and push/pull copolymer (P6)) have been prepared and characterized. Upon cyanation, a strong stabilization of the LUMO energy level was observed for P3 and P6. Based on their promising electro-optical properties, $\mathbf{P} 3$ is currently tested as $n$-type material in OFETs and as an electron-acceptor 
for the development of all-polymer solar cells while $\mathbf{P 6}$ is currently tested as an electron-donating material in OSCs.

Supplementary Materials: The following are available online, Figures $\mathrm{S} 1-\mathrm{S} 13{ }^{1} \mathrm{H}$ and ${ }^{13} \mathrm{C}-\mathrm{NMR}$ spectra, Figures S14-S17 Infrared spectra and Figures S18-S20 GPC chromatogram.

Author Contributions: T.B. and S.B. synthesized and characterized all the monomers and polymers. M.-A.L. performed theoretical calculations. O.A.I. and N.L. help characterizing polymers. M.L. supervised the project.

Funding: NSERC Discovery Grant and Apogée Sentinelle Nord Grant.

Acknowledgments: The authors acknowledge the Natural Sciences and Engineering Research Council of Canada (NSERC) and Université Laval (APOGÉE, Sentinelle Nord). Compute Canada and Calcul Québec are also thanked for access to computational facilities. The authors also thank Yuning Li (University of Waterloo, Ontario, CANADA) for useful discussions.

Conflicts of Interest: The authors declare no conflict of interest.

\section{References}

1. Lu, L.; Zheng, T.; Wu, Q.; Schneider, A.M.; Zhao, D.; Yu, L. Recent advances in bulk heterojunction polymer solar cells. Chem. Rev. 2015, 115, 12666-12731. [CrossRef] [PubMed]

2. Etxebarria, I.; Ajuria, J.; Pacios, R. Solution-processable polymeric solar cells: A review on materials, strategies and cell architectures to overcome 10\%. Org. Electron. 2015, 19, 34-60. [CrossRef]

3. Sondergaard, R.; Hösel, M.; Angmo, D.; Larsen-Olsen, T.T.; Krebs, F.C. Roll-to-roll fabrication of polymer solar cells. Mater. Today 2012, 15, 36-49. [CrossRef]

4. Hösel, M.; Dam, H.F.; Krebs, F.C. Development of lab-to-fab production equipment across several length scales for printed energy technologies, including solar cells. Energy Tech. 2015, 3, 293-301. [CrossRef]

5. Tsai, P.T.; Tsai, C.Y.; Wang, C.M.; Chang, Y.F.; Meng, H.F.; Chen, Z.K.; Lin, H.W.; Zan, H.W.; Horng, S.F.; Lai, Y.C.; et al. High-efficiency polymer solar cells by blade coating in chlorine-free solvents. Org. Electron. 2014, 15, 893-903. [CrossRef]

6. Berny, S.; Blouin, N.; Distler, A.; Egelhaaf, H.J.; Krompiec, M.; Lohr, A.; Lozman, O.R.; Morse, G.E.; Nanson, L.; Pron, A.; et al. Solar trees: First large-scale demonstration of fully solution coated, semitransparent, flexible organic photovoltaic modules. Adv. Sci. 2016, 3, 1500342. [CrossRef] [PubMed]

7. Zhang, S.; Ye, L.; Hou, J. Breaking the 10\% Efficiency Barrier in Organic Photovoltaics: Morphology and device optimization of well-known PBDTTT polymers. Adv. Energy Mater. 2016, 6, 1502529. [CrossRef]

8. Ouyang, X.; Peng, R.; Ai, L.; Zhang, X.; Ge, Z. Efficient polymer solar cells employing a non-conjugated small electrolyte. Nat. Photonics 2015, 9, 520-524. [CrossRef]

9. Zhou, H.; Zhang, Y.; Mai, C.K.; Collins, S.D.; Bazan, G.C.; Nguyen, T.Q.; Heeger, A.J. Polymer homo-tandem solar cells with best efficiency of 11.3\%. Adv. Mater. 2015, 27, 1767-1777. [CrossRef] [PubMed]

10. Zhao, W.; Li, S.; Yao, H.; Zhang, S.; Zhang, Y.; Yang, B.; Hou, J. Molecular optimization enables over 13\% in organic solar cells. J. Am. Chem. Soc. 2017, 139, 7148-7151. [CrossRef] [PubMed]

11. Zhang, S.; Qin, Y.; Zhu, J.; Hou, J. Over 14\% Efficiency in polymer solar cells enable by a chlorinated polymer donor. Adv. Mater. 2018, 30, 1800868. [CrossRef] [PubMed]

12. Kang, I.; Yun, H.J.; Chung, D.S.; Kwon, S.K.; Kim, Y.H. Record high hole mobility in polymer semiconductors via side-chain engineering. J. Am. Chem. Soc. 2013, 135, 14896-14899. [CrossRef] [PubMed]

13. Yun, H.J.; Kang, S.J.; Xu, Y.; Kim, S.O.; Kim, Y.H.; Noh, Y.Y.; Kwon, S.K. Dramatic inversion of charge polarity in Diketopyrrolopyrrole-based organic field-effect transistors via simple nitrile group substitution. Adv. Mater. 2014, 26, 7300-7307. [CrossRef] [PubMed]

14. Mercier, L.G.; Leclerc, M. Direct (Hetero)Arylation: A new tool for polymer chemists. Acc. Chem. Res. 2013, 46, 1597-1605. [CrossRef] [PubMed]

15. Bura, T.; Blaskovits, T.; Leclerc, M. Direct(hetero)arylation polymerization (DHAP): Trends and perspectives. J. Am. Chem. Soc. 2016, 138, 10056-10071. [CrossRef] [PubMed]

16. Pouliot, J.-R.; Grenier, F.; Blaskovits, T.; Beaupré, S.; Leclerc, M. Direct (Hetero)arylation polymerization: Simplicity for conjugated polymers synthesis. Chem. Rev. 2016, 116, 14225-14274. [CrossRef] [PubMed]

17. Nitti, A.; Po, R.; Bianchi, G.; Pasini, D. Direct Arylation strategies in the synthesis of n-extended monomers for organic polymeric solar cells. Molecules 2017, 22, 21. [CrossRef] [PubMed] 
18. Hendsbee, A.; Li, Y. Performance Comparisons of polymer semiconductors synthesized by Direct (Hetero)Arylation Polymerization (DHAP) and conventional methods for organic thin film transistors and organic photovoltaics. Molecules 2018, 23, 1255. [CrossRef] [PubMed]

19. Gobalasingham, N.S.; Thompson, B.C. Direct Arylation Polymerization: A guide to optimal conditions for effective conjugated polymer. Prog. Polym. Sci. 2018, 83, 135-201. [CrossRef]

20. Nakabayashi, K. Direct Arylation Polycondensation as conjugated polymer synthesis methodology. Polym. J. 2018, 50, 475-483. [CrossRef]

21. Mercier, L.G.; Pron, A.; Leclerc, M. Direct Arylation/Heteroarylation Polycondensation Reaction. In Conjugated Polymers: A Practical Guide to Synthesis; RSC Publishing: Cambridge, UK, 2014; pp. $422-442$.

22. Leclerc, M.; Beaupré, S. Direct (Hetero)arylation Polymerization, Synthetic Methods for Conjugated Polymers and Carbon Materials; Wiley-VCH Verlag GmbH \& Co.: Weinheim, Germany, 2017; pp. 131-158.

23. Iizuka, E.; Wakioka, M.; Ozawa, F. Mixed-ligand approach to palladium-catalyzed direct arylation polymerization: Synthesis of donor-acceptor polymers with Dithienosilole (DTS) and Thienopyrroledione (TPD) units. Macromolecules 2015, 48, 2989-2993. [CrossRef]

24. Iizuka, E.; Wakioka, M.; Ozawa, F. Mixed-ligand approach to palladium-catalyzed Direct Arylation Polymerization: Effective prevention of structural defects using diamines. Macromolecules 2016, 49, 3310-3317. [CrossRef]

25. Wakioka, M.; Takahashi, R.; Ichihara, N.; Ozawa, F. Mixed-ligand approach to palladium-catalyzed Direct Arylation Polymerization: Highly selective synthesis of $n$-Conjugated polymers with Diketopyrrolopyrrole units. Macromolecules 2017, 50, 927-934. [CrossRef]

26. Bura, T.; Beaupré, S.; Ibraikulov, O.A.; Légaré, M.-A.; Quinn, J.; Lévêque, P.; Heiser, T.; Li, Y.; Leclerc, N.; Leclerc, M. New fluorinated dithienyl-diketopyrrolo-pyrrole monomers and polymers for organic electronics. Macromolecules 2017, 50, 7080-7090. [CrossRef]

27. Bura, T.; Beaupré, S.; Légaré, M.-A.; Quinn, J.; Rochette, E.; Blaskovits, J.T.; Fontaine, F.-G.; Pron, A.; Li, Y.; Leclerc, M. Direct Heteroarylation Polymerization: Guidelines for defect-free conjugated polymers. Chem. Sci. 2017, 8, 3913-3925. [CrossRef] [PubMed]

28. Choi, H.; Ko, S.J.; Kim, T.; Morin, P.O.; Walker, B.; Lee, B.H.; Leclerc, M.; Kim, J.Y.; Heeger, A.J. Small-bandgap polymer solar cells with unprecedented short-circuit current density and high fill factor. Adv. Mater. 2015, 27, 3318-3324. [CrossRef] [PubMed]

29. Li, J.; Zhao, Y.; Tan, H.S.; Guo, Y.; Di, C.A.; Yu, G.; Liu, Y.; Lin, M.; Lim, S.H.; Zhou, Y.; et al. A stable solution-processed polymer semiconductor with record high-mobility for printed transitors. Sci. Rep. 2012, 2, 754. [CrossRef] [PubMed]

30. Farnum, D.G.; Mehta, G.; Moore, G.G.I.; Siegel, F.P. Attempted reformatskii reaction of benzonitrile, 1,4-diketo-3,6-diphenylpyrrolo[3,4-c]pyrrole. A lactam analogue of pentalene. Tetrahedron Lett. 1974, 15, 2549-2552. [CrossRef]

31. Wallquist, O.; Lenz, R. 20 years of DPP pigments-Future perspectives. Macromol. Symp. 2002, 187, 617-629. [CrossRef]

32. Grzybowski, M.; Gryko, D.T. Diketopyrrolopyrrole: Synthesis, Reactivity, and Optical Properties. Adv. Opt. Mater. 2015, 3, 280-320. [CrossRef]

33. Yi, Z.; Wang, S.; Liu, Y. Design of high-mobility diketopyrrolopyrrole-based $\pi$-conjugated copolymers for organic thin-film transistors. Adv. Mater. 2015, 27, 3589-3606. [CrossRef] [PubMed]

34. Li, W.; Hendriks, K.H.; Wienk, M.M.; Janssen, R.A.J. Diketopyrrolopyrrole polymers for organic solar cells. Acc. Chem. Res. 2016, 49, 78-85. [CrossRef] [PubMed]

35. Dubnik, A.S.; Aldrich, T.J.; Eastham, N.D.; Chang, R.P.H.; Facchetti, A.; Marks, T.J. Tin-free direct C-H arylation polymerization for high photovoltaic efficiency conjugated copolymers. J. Am. Chem. Soc. 2016, 48, 15699-15709.

36. Nitti, A.; Signorile, M.; Boiocchi, M.; Bianchi, G.; Po, R. PBDTTPD for plastic solar cells via $\mathrm{Pd}(\mathrm{PPh} 3) 4-$ catalyzed direct(hetero)arylation polymerization. J. Mater. Chem. A 2016, 4, 17163-17170.

37. Greve, D.R.; Apperloo, J.J.; Janssen, R.A.J. Synthesis and characterisation of novel regioregular polythiophenes 2-tuning the redox properties. Eur. J. Org. Chem. 2001, 3437-3443. [CrossRef]

38. Liu, M.S.; Jiang, X.; Liu, S.; Herguth, P.; Jen, A.K.-Y. Effect of cyano substituents on electron affinity and electron-transporting properties of conjugated polymers. Macromolecules 2002, 35, 3532-3538. [CrossRef] 
39. Seri, M.; Bolognesi, M.; Chen, Z.; Lu, S.; Koopman, W.; Facchetti, A.; Muccini, M. Fine structural tuning of cyanated dithieno[3,2-b:2', $\left.3^{\prime}-\mathrm{d}\right]$ silole-oligothiophene copolymers: Synthesis, characterization, and photovoltaic response. Macromolecules 2013, 46, 6419-6430. [CrossRef]

40. Qiu, M.; Brandt, R.G.; Niu, Y.; Bao, X.; Yu, D.; Wang, N.; Han, L.; Yu, L.; Xia, S.; Yang, R. Theoretical study on the rational design of cyano-substituted P3HT materials for OSCs: Substitution effect on the improvement of photovoltaic performance. J. Phys. Chem. C 2015, 119, 8501-8511. [CrossRef]

41. Xiong, Y.; Qiao, X.; Li, H. Nitrile-substituted thienyl and phenyl units as building blocks for high performance n-type polymer semiconductors. Polym. Chem. 2015, 6, 6579-6584. [CrossRef]

42. Nakabayashi, K.; Otani, H.; Mori, H. Benzodithiophene-based low band-gap polymers with deep HOMO levels: synthesis, characterization, and photovoltaic performance. Polym. J. 2015, 47, 617-623. [CrossRef]

43. Kim, H.G.; Kim, M.; Clement, J.A.; Lee, J.; Shin, J.; Hwang, H.; Sin, D.H.; Cho, K. Energy level engineering of donor polymers via inductive and resonance effects for polymer solar cells: effects of cyano and alkoxy substituents. Chem. Mater. 2015, 27, 6858-6868. [CrossRef]

44. Casey, A.; Han, Y.; Fei, Z.; White, A.J.P.; Anthopoulos, T.D.; Heeney, M. Cyano substituted benzothiadiazole: a novel acceptor inducing n-type behaviour in conjugated polymers. J. Mater. Chem. C 2015, 3, 265-275. [CrossRef]

45. Casey, A.; Dimitrov, S.D.; Shakya-Tuladhar, P.; Fei, Z.; Nguyen, M.; Han, Y.; Anthopoulos, T.D.; Durrant, J.R.; Heeney, M. Effect of systematically tuning conjugated donor polymer lowest unoccupied molecular orbital levels via cyano substitution on organic photovoltaic device performance. Chem. Mater. 2016, 28, 5110-5120. [CrossRef]

46. Casey, A.; Green, J.P.; Shakya Tuladhar, P.; Kirkus, M.; Han, Y.; Anthopoulos, T.D.; Heeney, M. Cyano substituted benzotriazole based polymers for use in organic solar cells. J. Mater. Chem. A 2017, 5, 6465-6470. [CrossRef]

47. Heuvel, R.; van Franeker, J.J.; Janssen, R.A.J. Energy level tuning of poly(phenylene-alt-dithienobenzothiadiazole)s for low photon energy loss solar cells. Macromol. Chem. Phys. 2017, 218, 1600502. [CrossRef] [PubMed]

48. Liu, X.; Li, M.; He, R.; Shen, W. Theoretical investigations on fluorinated and cyano copolymers for improvements of photovoltaic performances. Phys. Chem. Chem. Phys. 2014, 16, 311-323. [CrossRef] [PubMed]

49. Suraru, S.-L.; Zschieschang, U.; Klauk, H.; Würthner, F. Diketopyrrolopyrrole as a $p$-channel organic semiconductor for high performance OTFTs. Chem. Commun. 2011, 47, 1767-1769. [CrossRef] [PubMed]

50. Zhao, Z.-W.; Pan, Q.-Q.; Li, S.-B.; Duan, Y.-A.; Geng, Y.; Zhang, M.; Su, Z.-M. A theoretical exploration of the effect of fluorine and cyano substitutions in diketopyrrolopyrrole-based polymer donor for organic solar cells. J. Mol. Graph. 2017, 77, 9-16. [CrossRef] [PubMed]

51. Roy, C.; Bura, T.; Beaupré, S.; Légaré, M.-A.; Sun, J.-P.; Hill, I.G.; Leclerc, M. Fluorinated Thiophene-Based Synthons: Polymerization of 1,4-dialkoxybenzene and Fluoro-Dithieno-2,1,3-benzothiadiazole by Direct Heteroarylation. Macromolecules 2017, 50, 4658-4667. [CrossRef]

52. Gorelski, S.I. Origins of regioselectivity if the palladium-catalyzed (aromatic) C-H bond metalation-deprotonation. Coord. Chem. Rev. 2013, 257, 153-164. [CrossRef]

53. Guo, C.; Quinn, J.; Sun, B.; Li, Y. Dramatically different charge transport properties of bisthienyl diketopyrrolopyrrole-bithiazole copolymers synthesized via two direct (hetero)arylation polymerization routes. Polym. Chem. 2016, 7, 4515-4524. [CrossRef]

54. Pouliot, J.R.; Sun, B.; Leduc, M.; Najari, A.; Li, Y.; Leclerc, M. A high mobility dpp-based polymer obtained via direct(hetero)arylation polymerization. Polym. Chem. 2015, 6, 278-282. [CrossRef]

55. Ha, J.S.; Kim, K.H.; Choi, D.H. 2,5-Bis(2-octyldodecyl)pyrrolo[3,4-c]pyrrole-1,4-(2H,5H)-dione-Based Donor-Acceptor Alternating Copolymer Bearing 5,5'-Di(thiophen-2-yl)-2,2'-biselenophene Exhibiting $1.5 \mathrm{~cm}^{2} \cdot \mathrm{V}^{-1} \cdot \mathrm{s}^{-1}$ Hole Mobility in Thin-Film Transistors. J. Am. Chem. Soc. 2011, 133, 10364-10367. [CrossRef] [PubMed]

56. Blouin, N.; Michaud, A.; Gendron, D.; Wakim, S.; Plesu, R.; Belletête, M.; Durocher, G.; Tao, Y.; Leclerc, M. Towards a Rational Design of Poly(2,7-carbazole) Derivatives for Solar Cells. J. Am. Chem. Soc. 2008, 130, 732-742. [CrossRef] [PubMed]

57. Zou, Y.; Gendron, D.; Aïch, B.R.; Najari, A.; Tao, Y.; Leclerc, M. A High-Mobility Low-Bandgap Poly(2,7-carbazole) Derivative for Photovoltaic Applications. Macromolecules 2009, 42, 2891-2894. [CrossRef] 
58. Li, Y.; Singh, S.P.; Sonar, P. A High Mobility P-Type DPP-Thieno[3,2-b]thiophene Copolymer for Organic Thin-Film Transistors. Adv. Mater. 2010, 22, 4862-4866. [CrossRef] [PubMed]

59. Conwell, E. Primary Photoexcitations. In Conjugated Polymers: Molecular Excitons Versus Semiconductor Band Model; Sariciftci, N.S., Ed.; World Scientific: Singapore, 1997.

60. Zhu, Y.; Champion, R.D.; Jenekhe, S.A. conjugated donor-acceptor copolymer semiconductors with large intramolecular charge transfer: Synthesis, optical properties, electrochemistry, and field effect carrier mobility of thienopyrazine-based copolymers. Macromolecules 2006, 39, 8712-8719. [CrossRef]

Sample Availability: Samples of the compounds are not available from the authors.

(C) 2018 by the authors. Licensee MDPI, Basel, Switzerland. This article is an open access article distributed under the terms and conditions of the Creative Commons Attribution (CC BY) license (http://creativecommons.org/licenses/by/4.0/). 